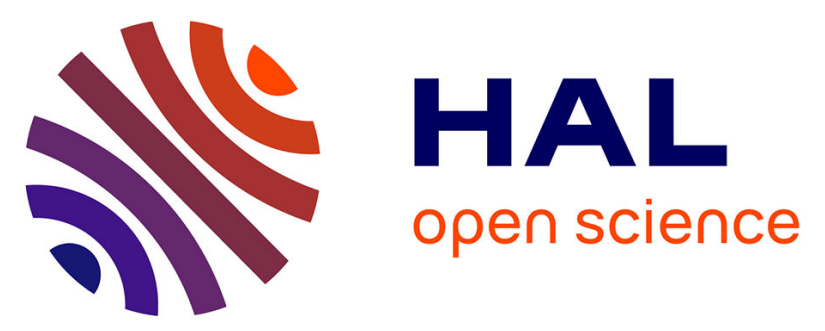

\title{
Limited influence of climatic gradients on the denudation of a Mediterranean carbonate landscape
}

Franck Thomas, Vincent Godard, Olivier Bellier, Lucilla Benedetti, Vincent

Ollivier, Magali Rizza, Fabrice Hollender, Valery Guillou, Georges Aumaitre, D.L. Bourles, et al.

\section{To cite this version:}

Franck Thomas, Vincent Godard, Olivier Bellier, Lucilla Benedetti, Vincent Ollivier, et al.. Limited influence of climatic gradients on the denudation of a Mediterranean carbonate landscape. Geomorphology, 2018, 316, pp.44-58. 10.1016/j.geomorph.2018.04.014 . hal-01797410

\section{HAL Id: hal-01797410 \\ https://hal-amu.archives-ouvertes.fr/hal-01797410}

Submitted on 22 May 2018

HAL is a multi-disciplinary open access archive for the deposit and dissemination of scientific research documents, whether they are published or not. The documents may come from teaching and research institutions in France or abroad, or from public or private research centers.
L'archive ouverte pluridisciplinaire HAL, est destinée au dépôt et à la diffusion de documents scientifiques de niveau recherche, publiés ou non, émanant des établissements d'enseignement et de recherche français ou étrangers, des laboratoires publics ou privés. 
Limited influence of climatic gradients on the denudation of a Mediterranean carbonate landscape

Franck Thomas, ${ }^{1, *}$, Vincent Godard ${ }^{1}$, Olivier Bellier ${ }^{1}$, Lucilla Benedetti ${ }^{1}$, Vincent Ollivier $^{2}$, Magali Rizza $^{1}$, Valéry Guillou ${ }^{1}$, Fabrice Hollender ${ }^{3,4}$, ASTER Team $^{1, a}$

1. Aix Marseille Univ, CNRS, IRD, INRA, Coll France, CEREGE, Aix-en-Provence, France

2. Aix Marseille Univ., CNRS, Minist Culture \& Com, LAMPEA, Aix-en-Provence, France

3. CEA, DEN, Saint Paul lez Durance, France

4. Université Grenoble Alpes/CNRS/IRD/IFSTTAR, ISTerre, Grenoble, France

*Corresponding author: thomas@cerege.fr

${ }^{a}$ Georges Aumaître, Didier L. Bourlès, Karim Keddadouche

Keywords : cosmogenic nuclides, denudation rates, carbonate, precipitation, climate, landscape evolution

How to cite this article : Franck Thomas, Vincent Godard, Olivier Bellier, Lucilla Benedetti, Vincent Ollivier, Magali Rizza, Valéry Guillou, Fabrice Hollender, ASTER Team (2018). Limited influence of 
climatic gradients on the denudation of a Mediterranean carbonate landscape, Geomorphology, doi:10.1016/j.geomorph.2018.04.014 


\section{$\underline{\text { Abstract }}$}

The dynamics of carbonate-dominated landscapes is still debated, and first-order questions pertaining to the respective importance of chemical and mechanical weathering processes or the influence of climatic variability on denudation rates are largely open. To address these issues, we investigate the denudation pattern across a climatic gradient in Provence, SE France. We focused on a series of major carbonate mountain ranges with elevation spanning 200 to $2000 \mathrm{~m}$ and associated with more than 2-fold variations in mean annual temperature and precipitation. We collected 25 samples from 10 different mountain ranges and quantified denudation rates through the measurement of their ${ }^{36} \mathrm{Cl}$ concentrations in order to explore tectonic and climatic controls on these carbonate landscapes evolution. We observe that most of our samples experience denudation rates in the $30-60 \mathrm{~mm} / \mathrm{ka}$ range (averaged over 5 to $40 \mathrm{ka}$ ), with no evident dependence on variations of mean annual temperature or precipitation. One range (Lure mountain) stands out as a significant outlier, with much higher denudation rates $(>100 \mathrm{~mm} / \mathrm{ka})$ than adjacent sites (Ventoux mountain) at the same elevation and experiencing similar presentday environmental conditions. We explore in details the climatic, tectonic and geomorphological contexts of these two ranges in order to understand the reasons for this apparent 3-fold difference in denudation rates. A regionally-documented major Holocene hillslope destabilization event appears to be a likely candidate to explain the observed lower ${ }^{36} \mathrm{Cl}$ concentrations at the top of the Lure mountain. At longer wavelengths, our regional dataset shows no clear control of modern precipitation gradients on denudation rates, consistent with previous observations in landscapes underlain by other lithologies. 


\section{1 - Introduction}

The respective influence of tectonic, climatic or anthropogenic forcings on landscapes evolution and their impact on the distribution of denudation rates in space and time is a major matter of debate in Earth Sciences (e.g. Portenga and Bierman, 2011; Riebe et al., 2001; Harel et al., 2016; Olen et al., 2016; Scherler et al., 2017). It is particularly interesting to understand the influence of climatic parameters such as temperature and precipitation on continental surfaces evolution and sediment fluxes (e.g. Tucker and Slingerland, 1997; Roe et al., 2003). Indeed, over Quaternary time scales, landscape dynamics is believed to be strongly impacted by the drastic environmental changes associated with glacial cycles (e.g. Schaller et al., 2002; Marshall et al., 2015; Tofelde et al., 2017). Understanding the impact of past climatic variability can help to better predict how landscapes will respond to projected changes in temperatures and precipitations in the future (Pelletier et al., 2015), across a wide range of spatial scales, from mineral surfaces to rock outcrops, landforms (hillslopes, hilltops or channels), regions and continents.

The Earth surface consists of a wide variety of lithologies including igneous, metamorphic and sedimentary rocks (Hartmann and Moosdorf, 2012). Despite this diversity, the mineralogical composition is dominated by silicates, which chemical weathering processes are characterized by a progressive degradation of the primary minerals, leading to various secondary products that constitute a solid residual available for further transformation and transport by erosion agents (e.g. Hilley et al., 2010; Mudd et al., 2013). From a surface processes perspective, carbonate lithologies stand out, due to the importance of congruent dissolution as a weathering agent, such that total dissolution can be achieved with only solute products left for transport (e.g. Ryb et al., 2014a). The existence of emblematic landscapes, such as karsts, associated with these specific 
lithologies demonstrate the role of dissolution as a potential driver of long-wavelength landscape evolution (Kaufmann and Braun, 2002; Fleurant et al., 2008). Contrastingly, a large part of our current understanding of the Earth surface dynamics relies on the analysis of processes responsible for solid mass transport by hillslopes and rivers (e.g. Roering et al. 2001; Whipple and Tucker 2002), and how they contribute to the emergence of first order landscape attributes such as ridges and valleys topography (Perron et al., 2009). In the case of carbonate landscapes, the potential dominance of a geomorphic agent whose activity is largely independent from topographic gradients question the applicability of usual Geomorphic Transport Laws to this type of environments (Dietrich et al., 2003). Furthermore, the high dependence of calcite dissolution on temperature, water availability and $\mathrm{pH}$ also highlights the importance of a better assessment of the climatic controls on carbonate landscape evolution (Kirstein et al., 2016; Levenson et al., 2017).

The variability and importance of these weathering processes for carbonate landscapes have lead to the development of numerous methods for the quantification of short-term carbonate dissolution (Gabrovsek, 2009), such as solute fluxes measurements (e.g. Gaillardet et al., 1999; Ryb et al., 2014), microtopography analysis (e.g. Furlani et al., 2009) as well as in situ or laboratory calcite dissolution experiments (Trudgill et al., 1994; Thorn et al., 2002; Liu et al., 2005; Plan, 2005; Kirstein et al., 2016). However, these proxies focus only on direct dissolution of carbonate rock mass in controlled environments not necessarily representative of more general weathering conditions. Notably, they do not allow to assess the effect of important processes contributing to long-wavelength landscape denudation such as mechanical weathering and solid products transport. In addition, these methods provide annual or decadal information and do not 
integrate over Quaternary climatic variability at 1 to 10 ka time scales (e.g. Kirchner et al., 2001), which might make them sensitive to high-frequency forcings.

The introduction of cosmogenic nuclides in quantitative geomorphology studies has revolutionized our way to assess rates of landscape evolution, in particular by averaging processes over centuries to 10s of ka (e.g. Lal, 1991; Gosse and Phillips, 2001; Granger and Riebe, 2013). For this reason, ${ }^{10} \mathrm{Be}$ has become an essential tool to quantify the denudation of quartz-rich landscapes from the scale of the outcrop to that of large continental river basins (e.g. von Blanckenburg, 2005), and has led to fundamental advances in our understanding of the evolution of these landscapes such as testing the relative importance of tectonic and climatic forcings on denudation (e.g. Riebe et al. 2001; Portenga and Bierman, 2011), or probing proposed Geomorphic Transport Laws (e.g. Ouimet et al., 2009; Scherler et al., 2017). In comparison, our ability to quantify denudation or study the evolution of carbonate landscapes has significantly lagged behind. This is a critical blind spot because these landscapes occupy approximately $13 \%$ of continental surfaces on Earth (Williams and Ford, 2006) and are major reservoirs for the carbon cycle. ${ }^{36} \mathrm{Cl}$ concentration measurements in carbonate rock surfaces can be used to quantify their exposure or denudation history (e.g. Stone et al., 1994; Schlagenhauf et al., 2010; Ryb et al., 2014a). While it offers important opportunities to constrain the dynamics of carbonate landscapes, it has been far less used than ${ }^{10} \mathrm{Be}$ in quantitative, process-oriented geomorphology studies (Ryb et al., 2014a\&b; Godard et al., 2016). There are several first order pending problems that could be addressed with this approach, and in particular the question of the climatic controls on the denudation of carbonate surfaces, because the postulated major role of congruent dissolution might result in high landscape sensitivity to water availability. In this study, we document ${ }^{36} \mathrm{Cl}$ concentrations measured in a large dataset of carbonate rock surfaces 
samples collected from 11 mountain ranges across a climatic gradient in Provence, SouthEastern France, in order to assess the sensitivity of denudation to environmental parameters.

2 - Development and applications of cosmogenic nuclides in carbonate landscapes

The Earth surface is constantly being bombarded by cosmic ray particles, which induce nuclear reactions with atoms in the atmosphere and in rocks on the Earth surface (e.g. Gosse and Phillips, 2001). These interactions, such as spallation by neutrons, result in the production of various rare nuclides, called cosmogenic nuclides, within rock formations located a few meters below the Earth surface. The measurements of these in situ-produced cosmogenic nuclide concentrations in various substrates is of great interest for surface processes quantification. In particular, it has been demonstrated (Lal, 1991) that for bedrock surfaces exposed to the cosmic ray particles and denuding at a constant rate for long enough, the induced cosmogenic nuclide production equilibrates the losses due to radioactive decay and mass removal linked to denudation processes. The cosmogenic nuclide concentration then reached at this steady-state is inversely proportional to the denudation rate of the surface (e.g. Granger and Riebe, 2013). This method provides a quantification of denudation rates, which are temporally averaged over the time period necessary to erode to a depth equivalent to the neutron characteristic attenuation length (approximately $60 \mathrm{~cm}$ in a substrate whose density is 2.5 g. $\mathrm{cm}^{-3}$ ) (Von Blanckenburg, 2005). 
In quartz-rich environments, the ${ }^{10} \mathrm{Be}$ and ${ }^{26} \mathrm{Al}$ cosmogenic nuclides, mainly produced through the spallation of the constitutive $\mathrm{O}$ and $\mathrm{Si}$ atoms, are used to quantify either local denudation rates at specific sampling sites from bedrock samples or basin-averaged denudation rates from river sediments (Brown et al., 1995; Bierman and Steig, 1996; Granger et al., 1996; Von Blanckenburg, 2005). These approaches are now routinely used in quantitative geomorphology studies to determine the rates of surface processes over the 1-100 ka time window. They have provided valuable insights into first order issues as, for example, the validation and calibration of fluvial or hillslope erosion formalisms (e.g. Ouimet et al., 2009; DiBiase and Whipple, 2011), the evaluation of the respective importance of tectonics and climate in controlling the denudation of mountain ranges (e.g. Bookhagen and Strecker, 2012; Godard et al., 2014) or the assessment of the evolution of surface processes over the last Ma (e.g. Charreau et al., 2011).

While cosmogenic nuclides have been intensively used to quantify denudation in settings dominated by quartz-rich lithologies for more than two decades, their use in areas dominated by carbonate lithologies is still in its early development stages. In such contexts, it is worth stressing again that congruent carbonate dissolution can act as a major weathering process, questioning the applicability of the classical slope-dependent Geomorphic Transport Laws (Dietrich et al., 2003) that have been validated by ${ }^{10} \mathrm{Be}$ derived denudation rate determinations in quartz rich settings (e.g. Ouimet et al., 2009).

In carbonate rocks, the ${ }^{36} \mathrm{Cl}$ cosmogenic nuclide is mainly produced through the spallation of $\mathrm{Ca}$ atoms and offers the possibility to investigate the exposure and denudation histories of carbonate surfaces. Dockhorn et al. (1991) conducted one of the earliest studies proposing the measurement of ${ }^{36} \mathrm{Cl}$ concentrations in limestones or dolomites in order to estimate denudation rates. Later, Stone et al. (1994) used a similar approach to constrain the denudation rates of carbonate 
surfaces in Australia. They reported denudation rates of $5 \mathrm{~mm} / \mathrm{ka}$ in various arid parts of Australia and significantly higher denudation rates of nearly $200 \mathrm{~mm} / \mathrm{ka}$ in the wet tropical highlands of Papua New Guinea.

While these pioneering studies demonstrated the relevance of the use of ${ }^{36} \mathrm{Cl}$ to investigate surface processes in carbonated settings, the systematic use of this cosmogenic nuclide was still hampered at that time by significant uncertainties associated to some of its production pathways, including up to $50 \%$ difference in reported ${ }^{36} \mathrm{Cl}$ production rates from spallation of $\mathrm{Ca}$ (Schimmelpfennig et al., 2009). A significant methodological effort was undertaken to alleviate these issues and to calibrate the rates associated with the different ${ }^{36} \mathrm{Cl}$ production modes (Schimmelpfennig et al., 2009; Marrero et al., 2016).

These studies paved the way for further developments of the use of ${ }^{36} \mathrm{Cl}$ in quantitative geomorphology studies. Matsushi et al. (2010) showed the importance of chemical dissolution in karst areas under subtropical climates in Japan and the greater impact of physical erosion in subarctic environments. Xu et al. (2013) came to similar conclusions studying samples collected in various climatic contexts in China and whose sampling altitudes ranged from 500 to 2300 meters above sea level. They determined denudation rates varying from 17 to $47 \mathrm{~mm} / \mathrm{ka}$ that are roughly inversely proportional to the Mean Annual Temperature (MAT) at the sampling sites. The authors suggest that, in their study area, chemical weathering is the dominant contributor to denudation, and that mechanical weathering could play a more important role in areas experiencing colder MAT, where freeze-thaw cycles occur. In their study of the Chauvet cave in the limestone karsts of Ardèche (France), Sadier et al. (2012) used ${ }^{36} \mathrm{Cl}$ to determine when the entrance of the cave was definitively closed by dating several rockfall events responsible for the accumulation of the sealing debris. In addition, the authors analyzed two samples from the 
surface located above the entrance and determined denudation rates similar to those from other studies under similar climates $(18.5$ and $21.5 \mathrm{~mm} / \mathrm{ka})$. Another surface ${ }^{36} \mathrm{Cl}$ measurement performed in South-Eastern France by Zerathe et al. (2013) provided a denudation rate of 35 $\mathrm{mm} / \mathrm{ka}$, consistent with results in northern Israel by Gran Mitchel et al. (2001) displaying a denudation rate of $29 \mathrm{~mm} / \mathrm{ka}$.

Ryb et al. (2014a) carried out additional developments for the use of ${ }^{36} \mathrm{Cl}$ in quantitative landscape evolution studies. In a tectonically stable, moderate-relief carbonate terrain in Israel, these authors combined denudation rates measurements with detailed investigations of the geomorphological properties of the sampling sites. They demonstrate that a transition between chemically-dominated and mechanically-dominated denudation in Israel occurs between 100 and $200 \mathrm{~mm}$ of Mean Annual Precipitation, suggesting that water availability has a major role in carbonate denudation in this context. Using a global compilation, Ryb et al (2014a) have noticed that ${ }^{36} \mathrm{Cl}$-based denudation rates increase linearly with MAP in sub-humid-Mediterranean climates but were independent from MAP in more humid climates. These results were interpreted in the sense that in semi-arid climatic conditions, chemical weathering is limited by the amount of precipitations whereas in more humid conditions, chemical weathering is apparently limited by the rate of carbonate mineral dissolution. In another study from the same area, Ryb et al. (2014b) compare long-term denudation rates to contemporary chemical weathering rates over variable time scales. Overall, their results suggest that on annual, decadal or $10^{4}$ years time scales, denudation is mostly controlled by chemical weathering whereas mechanical weathering has a much more limited influence. Furthermore, this study highlights the importance of the type of sampled landform and the distribution of soil cover. 
Ryb et al. (2015) provided paleo-precipitation gradient estimates along the western Dead Sea rift $\left(10^{4}-10^{7}\right.$ time scale) in order to shed light on the interactions between climate, denudation and tectonic uplift over the long term. Their study build on the idea that mass lost by dissolution over time is proportional to the time-integrated amount of precipitation. By combining total denudation estimated from a Turonian datum, denudation rates determined from ${ }^{36} \mathrm{Cl}$ concentrations and present-day mean annual precipitations (MAP), they propose that the effective precipitation gradient across the range was higher than the current one by at least $40 \%$ on average and that total precipitation at the $10^{7}$ time scale correlates with both denudation rates measured at the $10^{4}$ time scale and present-day MAP.

Godard et al. (2016) studied the relationship between denudation rates and local curvatures along the bedrock crests of the Petit Luberon in South-Eastern France. Using ${ }^{36} \mathrm{Cl}$ derived denudation rates and a high-resolution Digital Elevation Model, they demonstrated a direct correlation between curvature and denudation at sites at which the curvature is lower than $0.02 \mathrm{~m}^{-1}$ and a roughly constant denudation rate $(60-70 \mathrm{~mm} / \mathrm{ka})$ at sites characterized by higher curvatures. These results imply that mechanical weathering and clast transport contribute significantly to hillslope evolution in this setting, and that the observed limit in the rate of denudation at the hilltop might contribute to relief growth in mediterranean settings. Focusing on the same mountain range, Thomas et al. (2017) investigated the importance of slope-dependent denudation processes in carbonate lithologies. The authors compared denudation rates from samples originating from the mountain crest and basin-averaged rates from the flanks where they observed a much faster evolution $(70-200 \mathrm{~mm} / \mathrm{ka})$ than on the crest $(30-60 \mathrm{~mm} / \mathrm{ka})$, implying that despite the importance of chemical weathering in carbonate lithologies, mechanical transport 
plays a major role in the context of this relatively low elevation range (600-700 meters a.s.1) receiving moderate precipitation.

Overall, these recent studies illustrate a complex response of carbonate landscapes to environmental conditions, both in terms of the controlling parameters and the limiting processes at work. Further research is clearly needed to pinpoint their respective influences and assess the

full spectrum of their variations in the range of contexts where carbonate landscapes are present. First order questions, in line with some of the most salient problems in Earth Surface sciences, are still open, such as the importance of climatic gradients on surface denudation. Indeed, while the existing studies have already addressed this problem, the aggregated existing data remains equivocal and could be interpreted either as showing an overall increasing trend in denudation rate with MAP or as being a transition between two regimes with low sensitivity of denudation beyond a threshold in MAP. In this study we take advantage of an important climatic gradient over a carbonate landscape in SouthEast France to further test this idea.

$\underline{3-\text { Geological and geomorphological context }}$

Provence landscapes in South-Eastern France are dominated by East-West trending ranges originating from the Pyrenean orogeny during the Late Cretaceous to Early Tertiary (figure 1). The associated structures were subsequently reactivated as normal faults during the Oligocene, and as reverse strike-slip faults during the Miocene Alpine orogeny (Roure et al., 1992; Baroux et al., 2001; Champion et al., 2000; Chardon and Bellier, 2003; Molliex et al., 2011). The latest 
deformation phase was followed by the uplift and rejuvenation of pre-existing ranges (Siame et al., 2004; Bestani et al., 2016). However, various studies using diverse methodologies indicate that post-Miocene deformation rates are low in Provence (Chardon et al., 2005; Cushing et al., 2008; Nocquet, 2012). The ranges are mostly made of uplifted lower Cretaceous carbonate units. During the Late Miocene, the Provence area was heavily affected by the Messinian Salinity Crisis with a $1500 \mathrm{~m}$ drop of its Mediterranean base level (e.g. Clauzon, 1982; Gautier et al., 1994; Krijgsman et al., 1999; Mocochain et al., 2009). As described by these authors, this perturbation deeply imprinted the fluvial network, triggering intense regressive river erosion and the creation of deep canyons, which were later filled by marine and continental sediments once the Mediterranean Sea was again connected to the Atlantic Ocean. On average, the elevation in western Provence progressively increases from South to North. The crests of the main carbonate ranges (figure 1) reach altitudes ranging from 200 to 1900 meters, which induces a significant diversity in the climatic conditions. The Ventoux-Lure mountain marks the geological limit of Provence to the North. It is the highest mountain range in the region, reaching 1920 and $1800 \mathrm{~m}$ at the Ventoux and Lure mountains, respectively. Forty kilometers South of the Ventoux-Lure range, the Luberon and Alpilles mountains form another major EW system. From East to West, the Luberon range is composed of the Manosque fold (altitude: $\sim 800$ meters), the Grand Luberon (altitude: $\sim 1100$ meters) and the Petit Luberon (altitude: $\sim 700$ meters). The Alpilles, to the West, are separated from the Luberon by the NorthSouth Salon-Cavaillon fault, and rise to lower altitudes $(470 \mathrm{~m})$, with a well-developed plateau surface. Further East, the major features defining Provence landscapes are the Sainte Victoire and Sainte Baume mountains, both higher than 1000 meters. Smaller ranges also contribute to Provence landscapes such as the Costes (450 meters) and La Fare (200 meters) ranges and, 
bordering the Mediterranean coast, the Nerthe ( 250 meters) and the Calanques (450 meters) massifs, respectively located to the West and to the East of Marseille. These sites were selected and sampled to provide a wide distribution of elevations and climatic settings, especially for Mean Annual Temperatures (ranging from 5 to $16^{\circ} \mathrm{C}$ ) and Precipitation (ranging from 500 to $1400 \mathrm{~mm} / \mathrm{yr}$ ). Such diversity will allow to gain insights into the denudation pattern at the scale of a geologically coherent regional context and to specify the importance of climatic gradients in controlling the respective importance of physical and chemical weathering $\begin{array}{llll}\text { processes } & \text { in } & \text { carbonate }\end{array}$

\section{4 - Methods}

${ }^{36} \mathrm{Cl}$ concentrations were measured in carbonate samples from 25 sites distributed over 10 mountain ranges in Provence, South-Eastern France. The sampled ranges were, from North to South, the Ventoux and the Lure mountains, the Grand Luberon, the Alpilles, the Costes, the Sainte Victoire, the Sainte Baume, the La Fare mountain, the Nerthe and the Calanques. We also added 39 samples from the Petit Luberon crest to this dataset (Godard et al., 2016; Thomas et al., 2017) (figure 2). Plateau or flat surfaces on the crest of each range were selected to collect carbonate bedrock from roughly circular areas of approximately 10 meters in diameter using a chisel and a hammer (figure 3) with a sampling depth of 3-4 cm. The sampling sites were restricted to the crests of these ranges to avoid the influence of material flux from upslope. There is no topographic shielding in such sampling configuration. All samples were collected on 
bedrock surfaces. We selected sites with no soil cover and no evidence of former significant regolith development. Moreover, significant snow shielding is very unlikely at our sampling sites in Lure and Ventoux because snowfall is sporadic during the winter and these sites are located at narrow convex hilltops where snow is quickly removed by wind and downslope fluxes. Using a conservative value of $1 \mathrm{~m}$ of snow all over the winter duration yields a negligible shielding ( $>0.97$, Gosse and Phillips, 2001). Samples lithologies were homogeneous and consisted of consolidated and massive Cretaceous and Jurassic limestones. The sampled sites have Mean Annual Temperature (MAT) ranging from $5^{\circ} \mathrm{C}$ at the Ventoux and the Lure mountains to $16^{\circ} \mathrm{C}$ at the locations closest to the Mediterranean Sea (table 1). Mean Annual Precipitation (MAP) are roughly inversely correlated to MAT, with approximately $500-600 \mathrm{~mm}$ at seaside locations and up to $1400 \mathrm{~mm}$ over the Ventoux and Lure mountains (figure 4). The sampling sites were specifically selected to encompass the largest possible range in MAT and MAP, which led to a wide range of elevation in the choice of sampling sites, from 200 meters at the Nerthe and the Alpilles ranges up to 1900 meters a.s.l at the Ventoux Mount (figure 4). After collection, samples were crushed and sieved, and chlorine was chemically extracted using $\mathrm{AgCl}$ precipitation following the approach described by Schlagenhauf et al. (2010). Natural chlorine (hereafter $\mathrm{Cl}_{\text {nat }}$ ) and ${ }^{36} \mathrm{Cl}$ concentrations were then determined via isotope dilution accelerator mass spectrometry based on the measured ${ }^{35} \mathrm{Cl} /{ }^{37} \mathrm{Cl}$ and ${ }^{36} \mathrm{Cl} /{ }^{35} \mathrm{Cl}$ ratio measurements performed at the French national accelerator mass spectrometry (AMS) facility ASTER (Accélérateur pour les Sciences de la Terre, Environnement, Risques) at CEREGE, Aix-enProvence, France (Arnold et al., 2013). The ${ }^{36} \mathrm{Cl}$ concentrations were normalised to the ${ }^{36} \mathrm{Cl}$ standard KNSTD1600 with a nominal ${ }^{36} \mathrm{Cl} /{ }^{35} \mathrm{Cl}$ value of $2.11 \pm 0.0610^{12}$ (Sharma et al., 1990; Fifield et al., 1990). 
In addition to denudation rates determination using cosmogenic nuclides, local curvature and slope at each sampling site were calculated using high-resolution Digital Elevation Models (DEM) with 1 meter resolution from the RGE ALTI database of the IGN (French National Institute of Geographical and Forest Information), in order to compare local topographic parameters and assess their influence on denudation. We used WorldClim (Fick and Hijmans, 2017) set of global climate rasters with a spatial resolution of $\sim 1 \mathrm{~km}$ (figure 4 ) to link the obtained denudation rates with climatic parameters (figure 5) such as MAP, MAT and temperature amplitude. The WorldClim data was compared to the Météo France climate records at nine weather stations located throughout Provence to test its robustness (see figure 4A for location). A slight difference in MAT and a more significant deviation in MAP was observed (figure 5). The MétéoFrance data was used to determine correction parameters using a linear regression and to recalculate the climatic data at all the sampling sites.

\section{$\underline{5-\text { Results }}$}

The measured ${ }^{36} \mathrm{Cl}$ concentrations range from $5.94 \times 10^{5}$ to $3.36 \times 10^{6}$ atoms $/ \mathrm{g}$ of rock, and the number of ${ }^{36} \mathrm{Cl}$ atoms in the samples range from $\sim 6 \times 10^{6}$ to $\sim 1.2 \times 10^{8}$, which is 2 to 3 orders of magnitude higher than those measured in the simultaneously processed chemical blanks $\left(10^{5}\right.$ atoms of ${ }^{36} \mathrm{Cl}$ ). The amount of $\mathrm{Cl}_{\text {nat }}$ measured in the samples is also 10 times higher than the amount measured in the processed chemical blanks. $\mathrm{Cl}_{\text {nat }}$ concentrations are on average $8.6 \mathrm{ppm}$ for the whole dataset, with all samples below $25 \mathrm{ppm}$ except one reaching $81 \mathrm{ppm}$, which is consistent with natural $\mathrm{Cl}$ concentrations measured in other similar studies (e.g. Xu et al., 2013). 
For our dataset the different production pathways of ${ }^{36} \mathrm{Cl}$ are, in average, as follows: spallation of target elements (78\%), slow negative muons capture (19\%) and thermal and epithermal neutron capture (3\%) (Schimmelpfennig et al., 2011). The ${ }^{36} \mathrm{Cl}$ production rate from spallation of calcium has been calibrated in Sicily by Schimmelpfennig et al. (2011) on Ca-rich feldspar at $42.2 \pm 4.8$ atoms $\mathrm{g} /$ year. We used this production rate because the Provence area is located at almost the same latitude and elevation as this calibration site, and because it has been determined on mineral fractions. Scaling with respect to latitude and elevation was performed considering constant geomagnetic field intensity and Stone (2000) scaling. Denudation rates were calculated using the approach of Schimmelpfennig et al. (2009). The decay constant used (2.303 \pm $0.016 \times 10^{6}$ year-1) corresponds to a ${ }^{36} \mathrm{Cl}$ half-life $\left(\mathrm{T}_{1 / 2}\right)$ of $3.014 \times 10^{5}$ years. The analytical uncertainties include counting statistics, machine stability and blank correction. We note that calculating the denudation rates with CRONUS-Earth approach, as recently described in Marrero et al. (2016), would change the denudation rates values by at most $30 \%$ mostly because the authors used a different production rate. This won't affect our interpretation which is based on relative difference between the yielded denudation rate and thus independent of the chosen production rate or calculation scheme. However, this becomes important when comparing values with other studies and we choose Schimmelpfennig et al. (2009) calculator to be able to compare our data with previously published values which used the same calculation scheme, and also because the ${ }^{36} \mathrm{Cl}$ production rate from spallation of $\mathrm{Ca}$, which is the most important production reaction for the samples in this study, was calibrated directly from mineral fractions in Schimmelpfennig et al. (2011).

Denudation rates across Provence deduced from our dataset range from 18.6 to $141.4 \mathrm{~mm} / \mathrm{ka}$ including outliers (see Table 1 and figure 6A). The interquartile range is 30 to $50 \mathrm{~mm} / \mathrm{ka}$, which 
is in agreement with denudation rates determined on mountain crests over the Mediterranean area (e.g. Ryb et al., 2014a; Godard et al., 2016; Thomas et al., 2017). The time period over which the determined denudation rates are integrated range from approximately 5000 years, considering the highest denudation rates, and up to 32000 years considering the lowest denudation rates. The lowest denudation rates are determined in the lowermost ranges, such as the Nerthe and Calanques massifs (approximately $200 \mathrm{~m}$ ), whereas the highest denudation rates are associated to the samples located at an altitude of $1800 \mathrm{~m}$ in the Lure mountain. A focus on each single range shows significant local-scale variability of the calculated denudation rates. For example, the Grand Luberon and Lure mountains display rates in the $55-117$ and $111-141 \mathrm{~mm} / \mathrm{ka}$ ranges, respectively. Smaller but noticeable variability is also observed at other sites, such as the Sainte Victoire (22-40 mm/ka), the Sainte Baume (34-51 mm/ka) and the Ventoux Mount (27-49 $\mathrm{mm} / \mathrm{ka}$ ). In the next section we develop an analysis of the observed variability in our dataset.

\section{$\underline{6 \text { - Discussion }}$}

Our dataset provides the opportunity to discuss the dynamics and controls on carbonate surface denudation across a wide range of environmental conditions. We first discuss the observed variability between the different sites, as well as inside a same range, and we then focus on the influence of the tectonic and climatic boundary conditions. At last we attempt to put our data in a

broader perspective by comparing with global denudation rates databases for both carbonates and quartz-rich landscapes.

\section{1 - Variability of denudation rates in Provence}


Our dataset provides extensive information on denudation rates from eleven mountain ranges in Provence, allowing a regional scale analysis of landscape evolution in a carbonate-dominated area. The determined denudation rates appear variable at the scale of both the individual ranges and the region. The former could be explained by local variations in the morphology at the sampling site (figure 6). Indeed, the analyzed samples have all been collected at the highest elevation of each range, but some were located on large plateau areas, such as in the Alpilles mountain, whereas others were collected on convex crests or on flat surfaces adjacent to cliffs (see figure 6D). As illustrated by data from the Petit Luberon, hilltop convexity is correlated with denudation rates determined at sampling locations on the crests (Godard et al., 2016) and could explain a significant amount of variability of the denudation rates ranging from 30 to $70 \mathrm{~mm} / \mathrm{ka}$ (figure 6D). Samples collected on a flat area but in the direct vicinity of a cliff display denudation rates that are in the $30-50 \mathrm{~mm} / \mathrm{ka}$ range but have artificially high surface convexity due to the size of the computation window (e.g. Petit Luberon, Costes). Samples collected on relatively narrow crests can exhibit high denudation rates (e.g. Grand Luberon, Lure). We also note that the distance between sampling locations and the Mediterranean Sea does not clearly impact the denudation rates reported for individual ranges (figure 7).

Most of the samples, collected at various altitudes, display denudation rates clustering in the 30$60 \mathrm{~mm} / \mathrm{ka}$ range despite contrasting climates ranging from the dry and hot coastal ranges of the Nerthe and Calanques massifs up to the highest, wettest and coldest sampling points at the top of the Ventoux Mount. This diversity of sampling sites encompasses a 3-fold and 2-fold changes in MAT and MAP, respectively. This range of denudation rates is consistent with data from other carbonate domains (e.g. Matsushi et al., 2010; Xu et al., 2013), including Mediterranean areas (Ryb et al., 2014a,b). 
Samples from the Lure mountain and, to a lesser extent, from the Grand Luberon, whose denudation rates are comprised in the $111-141 \mathrm{~mm} / \mathrm{ka}$ and $55-117 \mathrm{~mm} / \mathrm{ka}$ ranges respectively, display significantly higher rates than the $30-60 \mathrm{~mm} / \mathrm{ka}$ values reported for the other mountain ranges in our dataset as well as for carbonate landscapes elsewhere (e.g. Levenson et al., 2017). Considering the data distribution displayed in figure $6 \mathrm{~A}$, the reasoning developed in the previous paragraph could be reversed and thus the low denudation rates reported at high elevation for the Ventoux considered as outliers. In this case, the dataset including the samples from the Lure mountain and from the Grand Luberon mountain range would display a significant dependence of the denudation rates relative to their respective elevation. As previously exposed, our dataset has been acquired to question whether altitude and climatic conditions influence carbonate denudation or if, on the contrary, denudation remains constant over a wide range of climatic conditions, meaning that out of range denudation rates, such as those observed at the Lure mountain, are caused by other specific local parameters. Therefore, the interpretation of this dataset specifically hinges on the question of the signification of the large denudation variability observed along the Ventoux-Lure axis, which are areas displaying similar elevations as well as similar mean annual climatic parameters. To address this fundamental conundrum, the possible tectonic, climatic or geomorphic causes for the observed denudation contrast are discussed below.

\section{2 - Importance of tectonic and climatic forcings}

The Ventoux and Lure mountains are morphologically separated by the NNE Sault graben (George, 1952). This Oligocene geological feature could have induced a decoupling of the 
tectonic uplift between the eastern (Lure) and western (Ventoux) sides of the graben that could have had repercussions during the late Quaternary. According to Bestani et al. (2016), this graben is linked to the deformation of the hanging wall of the Ventoux-Lure thrust system. Considering that the Sault graben could have partially disconnected the Ventoux mountain from the Alpine deformation field, this could potentially explain the faster denudation on the Lure mountain because it is located closer to the Alps. This would have therefore led to an East-West rock uplift gradient.

Bestani et al. (2016) constructed two North-South cross sections to estimate the shortening resulting from the various tectonic phases that affected Provence. The first section crossing the Ventoux mountain shows a significantly smaller late-Cretaceous early-Tertiary shortening than the second section crossing the Lure mountain (7.8\% vs. 26\%). However, the post-Eocene shortening is equivalent $(1.5 \mathrm{~km})$ along the two cross sections. The similar crest elevations between the two mountains also plead against an important differential finite uplift accumulated over the Late Cenozoic.

To assess the possibility of a tectonic control over relevant time-scales considering the integration time of our denudation rates $\left(\sim 10^{4}\right.$ years), we investigated the variability of morphological proxies for tectonic uplift across the Ventoux-Lure system. In steady-state landscapes, a simple relationship exists between slope (S) and drainage area (A) measured along rivers (Hack, 1957; Flint, 1974; Howard and Kerby, 1983; Kirby and Whipple, 2012), which can be written as the slope-drainage area relationship:

$\mathrm{S}=\mathrm{k}_{\mathrm{s}} \mathrm{A}^{-\theta}$ 
where ks is the channel steepness index and $\theta$ is the concavity. To allow easier inter-comparison between different river profiles, a normalized steepness index $\left(\mathrm{ks}_{\mathrm{n}}\right)$ can be calculated, using a fixed reference concavity (e.g. Kirby and Whipple, 2012). Under the assumption of homogeneity of the erodibility of the substrate for the considered catchments, the $\mathrm{ks}_{\mathrm{n}}$ parameter can be directly linked to tectonic uplift in geomorphological studies (Kirby et al. 2003, Wobus et al., 2006), and, in our case, a lateral variation of $\mathrm{ks}_{\mathrm{n}}$ along the Ventoux-Lure axis would evidence a gradient in rock uplift. A reference concavity of 0.5 was used to estimate averaged $\mathrm{ks}_{n}$ values for catchments over several ranges, and we calculated $\mathrm{ks}_{\mathrm{n}}$ values for $\sim 100$ catchments from both the northern and southern flanks of the Ventoux and Lure ranges (figure 8).

The results obtained indicate that the northern flank of the Ventoux mountain displays relatively higher $\mathrm{ks}_{\mathrm{n}}$ values than the Lure mountain, which would imply a more rapid recent uplift of the Ventoux mountain and conflicts with the observed pattern of denudation rates. Similar observations can be made from the distribution of the average long-wavelength slopes of the flanks of both mountains (figure 8). Therefore, we conclude that a difference in Quaternary tectonic forcing along the Ventoux-Lure system is not likely to be a viable explanation for the observed denudation rate contrast between the two ranges.

The East-West trending Ventoux-Lure system is approximately 70 kilometers long and is located at the Northern limit of Provence, and at the boundary between two different climatic domains. To the West, the Ventoux is under the influence of the Rhône valley climatic regime where the cool and dry Mistral wind dominates and results in low cloud cover throughout the year as well as scattered precipitations with sporadic storm events. To the East, the Lure mountain, located at the border of the Southern Alps region, is under the influence of the Alpine climate whose precipitations are more evenly distributed throughout the year. 
The ${ }^{36} \mathrm{Cl}$-derived denudation rates are averaged over approximately 5000 and 32000 years for the Lure and Ventoux mountain, respectively, and major climatic and geomorphic events occurring over these time intervals, such as the last deglaciation or Holocene climatic fluctuations, have to be considered in our interpretation of the denudation rates and could be one of the keys to understand their variability. In particular, the denudation rates calculated for the Ventoux integrate over the end of the last glacial period, whereas the denudation rates calculated at the Lure mountain only encompass the latter half of the Holocene.

High resolution DEM and orthophotos show a dense network of gullies incising the southern flank of the Lure mountain (figure 9) and suggest the recent development of widespread regressive erosion that almost reaches the crest, whereas no such geomorphic response can be observed near the summit of the Ventoux where our sampling site is located. A major postglacial valley sediment filling episode due to massive denudation of mountain flanks at the beginning of the Holocene has been recognized in the Southern Alps (Miramont et al., 2004) and may explain the large regressive erosion observed on the Lure mountain. One consequence of such major hillslope destabilisation would have been to increase denudation rates resulting in present-day significantly lower ${ }^{36} \mathrm{Cl}$ concentrations. In this case the samples from the Lure mountain summit would be out-of-equilibrium with respect to ${ }^{36} \mathrm{Cl}$ accumulation and could not be directly interpreted in terms of denudation rates. Due to its position to the West, the Ventoux is disconnected from the Durance river base level and associated Alpine influence and, for that reason, was not affected by the erosion event. Most paleoenvironmental studies focusing on ${ }^{14} \mathrm{C}$ or pollen analysis to reconstruct past environments (e.g. Thinon, 2007) suggest that surface conditions and vegetation cover has remained stable throughout the first half of the Holocene on the Ventoux, even though agricultural activities may have induced a change in vegetation during 
the last 4000 years mainly on the summit area. Additionally, the Durance glacier was located directly East of the Lure range and had a major impact on the local morphology until at least 20 ka BP (Rosique, 2004), whereas the Ventoux was not directly affected by these major perturbations occurring in the upper and middle Durance valley. Collectively, these observations support the idea that the observed contrast in denudation rates and ${ }^{36} \mathrm{Cl}$ concentrations along the Ventoux-Lure System results from a major climatically-triggered geomorphological change in the Durance valley. A significant change in hillslope dynamics and associated denudation could have been triggered by two nonexclusive types of perturbations : (1) an abrupt fall in the base level of the gully network incising the northern flank of the Lure range, possibly related to the retreat of the Durance glacier, and (2) a drastic modification of the regolith transport parameters, associated with changes in temperature, precipitation and land cover. The melting of the Alpine ice cap at the end of the last deglaciation can also explain the observed high geodetic vertical motion rates and gradients in the external parts of the Alps (Champagnac et al., 2007), which could influence present-day denudation patterns.

\section{$\underline{6.3 \text { - Global perspective on carbonate landscapes denudation }}$}

The dataset acquired during this study was compared to a global compilation of denudation rates derived from ${ }^{36} \mathrm{Cl}$ concentrations measured in carbonates (Levenson et al., 2016) that spans a broad spectrum of climatic settings, with MAP ranging from almost 0 to $2500 \mathrm{~mm}$ (figure 10). Our dataset encompasses the intermediate 500 to $1500 \mathrm{~mm}$ MAP domain. The reported denudation rates are mostly within the $20-60 \mathrm{~mm} / \mathrm{ka}$ range which is compatible with observations from other settings experiencing comparable or wetter climatic conditions. Notable deviations are (1) the high-convexity crests of the Petit Luberon where denudation is accelerated by regolith mass transport at the surface (Godard et al., 2016) and reaches 70-80 mm/ka and (2) 
the Lure mountain summit whose particular geomorphic history has been discussed above. The lack of any significant correlation with MAP in our dataset is consistent with results from other non-arid regions, where water availability does not act as a limiting factor. Samples from drier regions display significantly lower denudation rates $(<20 \mathrm{~mm} / \mathrm{ka}$, Ryb et al., 2014a,b), and this contrast supports the proposition by Ryb et al (2014a) that, for steep hillslopes, a fundamental MAP threshold exists around 100-300 mm, below which mechanical weathering processes become the main drivers of landscape denudation.

Many insights in the geomorphological evolution of carbonates rocks and landscapes have been derived from other methodologies. In another Mediterranean area, Furlani et al. (2009) have investigated the lowering rates of limestone surfaces using micro erosion measurements at various sites in the Adriatic region. For inland karst measurement stations, which are not subjected to coastal geomorphological forcings, they report lowering rates of $0.018 \mathrm{~mm} / \mathrm{yr}$, and as low as $0.009 \mathrm{~mm} / \mathrm{yr}$ for the inland Istrian Karst. These surface lowering rates are significantly less than denudation rates derived from ${ }^{36} \mathrm{Cl}$ concentrations measurements under comparable climatic conditions (figure 10), but consistent with low rates derived from similar methodologies or limestone tablets dissolution experiments (e.g. Plan, 2005; Gabrovsek, 2009 and references therein). It is to be noted that these experiments integrate weathering processes over at most a few decades, and thus do not incorporate major climatic and environmental perturbations occurring on Holocene timescales such as the regressive erosion event we considered to discuss the apparent high denudation rates at the top of the Lure mountain. Furthermore, due to the experimental strategy of most of these studies, they typically measure the effects of surface lowering or mass loss due mainly to chemical weathering, whereas the denudation signal obtained through cosmogenic nuclides measurements is by definition the sum of chemical and 
mechanical processes. Such difference could be one of the reasons for the lower rates reported by these experiments and would further highlight the importance of mechanical weathering agents breaking down bedrock mass and producing sediment clasts available for transport in the evolution of carbonate landscapes (Thomas et al., 2017).

We also attempt to put the question of an eventual climatic control on carbonate landscapes into a broader context by comparing the existing ${ }^{36} \mathrm{Cl}$ denudation rates with a global compilation of bedrock ${ }^{10} \mathrm{Be}$ denudation rates in quartz-rich settings (Portenga and Bierman, 2011, figure 11). The broad range of climatic and geologic settings investigated as well as the non-constrained influence of site-specific morphological contexts (slope, curvature) are probably major contributors to the observed high variability over given MAP intervals. Such a large data dispersion is inherent to these global compilations, and we acknowledge the associated discussion should be treated cautiously and as a general investigation of the first order trends. Nevertheless, we observe two important features that we think worthy of consideration in this comparison of the two datasets. First, even if the datasets display numerous overlaps, when considering average values over similar ranges of MAP the ${ }^{36} \mathrm{Cl}$ derived denudation rates in carbonate settings are systematically at least 2 times higher than the ${ }^{10} \mathrm{Be}$ derived denudation rates in quartz-rich settings. This difference would imply significantly shorter residence times of carbonate terrains at the surface of the Earth with respect to other types of bedrock. Second, the exponents of the general power-law trends extracted from both datasets are similar $(\sim 0.5)$ and suggest a weak dependence of surface denudation on the variability of precipitation over the range of investigated MAP. Furthermore, for both datasets, the existence of this shallow trend appears to be mostly due to very low denudation in arid regions, whereas results from temperate to humid regions show no apparent correlation and suggest that water availability is not a 
limiting factor on denudation over a large range of precipitation conditions at the Earth surface. Assessing the extent of climatic controls, mainly through precipitation, on landscape evolution is a long-standing issue in geomorphology, and this general result is consistent with independent observations in specific climatic and tectonic settings (e.g. Riebe et al., 2001; Godard et al., 2014; Gasparini and Whipple, 2014). It is noteworthy that most of these studies downplaying the role of climate on denudation focused on silicate-rich terrains. The fact that such a result appears to hold in non-arid carbonate terrains, even though these domains are often considered to be dominated by chemical weathering, provides further support to the idea of a limited impact of precipitation gradients on landscape denudation at 1-100 ka timescales.

\section{7 - Conclusion}

We collected a well distributed dataset documenting denudation patterns across a carbonatedominated region. The denudation rates deduced from ${ }^{36} \mathrm{Cl}$ concentrations in our 25 samples and the 39 samples from the Petit Luberon (Godard et al;, 2016 and Thomas et al., 2017) are consistent with the range of denudation rates observed in other carbonate domains. We note however a discrepancy in terms of denudation rates between the Ventoux $(30-40 \mathrm{~mm} / \mathrm{ka})$ and the Lure $(110-140 \mathrm{~mm} / \mathrm{ka})$ mountains. It is possible that the apparent decoupling in behavior between these two ranges is of tectonic origin or results from strong morphological events following the end of the last glacial period. Nevertheless, this study is one of the first to document ${ }^{36} \mathrm{Cl}$-computed denudation rates for carbonate rocks across a wide array of altitudes and variable mean annual temperatures and precipitations. Calculated denudation rates appear to be strongly impacted by changes in surface processes dynamics induced by climatic variability at 
the scale of the Holocene. On the other hand, the regional distribution of denudation rates suggests a low sensitivity to climatic spatial gradients over the range of conditions investigated here. We focused here on MAP as the main climatic variable to evaluate the response of carbonate surfaces, however subsequent studies should also focus on multifactorial environmental controls, including temperature (Marshall et al., 2015) but also the complex influence of variations in vegetation (e.g. Torres Acosta et al., 2015; Schaller et al., 2018). Indeed, the influence of vegetation on $\mathrm{CO}_{2}$ partial pressure in the subsurface is potentially an important control on carbonate denudation (e.g. Calmels et al., 2014).

Acknowledgments

This study was supported by the ECCOREV Research Federation, INSU-CNRS and the Cashima Research Project (funded by the CEA Cadarache and ITER Organisation). Franck Thomas benefitted from a PhD scholarship funded by the CEA and the Conseil Regional PACA. We thank the Parc Naturel Régional du Luberon and the Office National des Forêts and the Plan d'Aups city for facilitating access to our field sites. The $36 \mathrm{Cl}$ measurements were performed at the ASTER AMS national facility (CEREGE, Aix en Provence) which is supported by the INSU/CNRS, the ANR through the "Projets thematiques d'excellence" programme for the "Equipements d'excellence" ASTER-CEREGE action, IRD and CEA. This work is also a contribution to the Labex OT-Med (n ANR-11-LABX-0061) funded by the French Government "Investissements d'Avenir" programme of the French National Research Agency (ANR) through the $A^{*}$ MIDEX project (n ANR-11-IDEX-0001-02). 
Table

\begin{tabular}{|c|c|c|c|c|c|c|c|c|c|c|c|c|c|}
\hline $\begin{array}{c}\text { Sample } \\
\text { ID }\end{array}$ & Mountain range & Type & Longitude & Latitude & Altitude & {$\left[{ }^{36} \mathrm{Cl}\right]$} & {$[\mathrm{Cl}]$} & {$[\mathrm{Ca}]$} & Denudation rate & MAT & MAP & Slope & Curvature \\
\hline & & & ${ }^{\circ} \mathrm{E}$ & ${ }^{\circ} \mathrm{N}$ & $\mathrm{m}$ & $10^{5}$ atom $/ \mathrm{g}$ & $\mathrm{ppm}$ & $\%$ & $\mathrm{~mm} / \mathrm{ka}$ & ${ }^{\circ} \mathrm{C}$ & $\mathrm{mm} / \mathrm{yr}$ & $\circ$ & $\mathrm{m}-1$ \\
\hline NE2 & Nerthe & Bedrock & 5.2403 & 43.3410 & 211 & $\begin{array}{c}13.22 \pm \\
0.49 \\
\end{array}$ & 24.25 & 40.5 & $29 \pm 3.1$ & 14.4 & 558 & 2.39 & 0.011 \\
\hline NE3 & Nerthe & Bedrock & 5.1596 & 43.3562 & 163 & $\begin{array}{c}16.40 \pm \\
0.58 \\
\end{array}$ & 9.61 & 38.7 & $18.6 \pm 2$ & 14.7 & 541 & 3.27 & 0.003 \\
\hline CA1 & Calanques & Bedrock & 5.4363 & 43.2200 & 230 & $\begin{array}{c}11.15 \pm \\
0.37\end{array}$ & 13.96 & 40.8 & $34.4 \pm 3.6$ & 14.8 & 573 & 6.86 & 0.025 \\
\hline CA3 & Calanques & Bedrock & 5.4638 & 43.2321 & 382 & $\begin{array}{c}11.64 \pm \\
0.45 \\
\end{array}$ & 10.17 & 39.7 & $35.4 \pm 3.8$ & 13.9 & 652 & 15.44 & 0.027 \\
\hline AL1 & Alpilles & Bedrock & 5.0245 & 43.7561 & 260 & $16.37 \pm 0.5$ & 4.59 & 47.1 & $21.6 \pm 2.3$ & 13.6 & 668 & 2.79 & 0.002 \\
\hline AL4 & Alpilles & Bedrock & 5.0318 & 43.7620 & 240 & $\begin{array}{c}10.33 \pm \\
0.54\end{array}$ & 7.14 & 38.3 & $35.8 \pm 4$ & 13.8 & 657 & 3.39 & 0.011 \\
\hline SB2 & Sainte Baume & Bedrock & 5.7332 & 43.3187 & 984 & $\begin{array}{c}12.12 \pm \\
0.49 \\
\end{array}$ & 3.81 & 40.8 & $50.6 \pm 5.5$ & 12.2 & 827 & 13.10 & 0.057 \\
\hline SB5 & Sainte Baume & Bedrock & 5.6979 & 43.3143 & 997 & $17.19 \pm 0.6$ & 7.31 & 40 & $34.2 \pm 3.6$ & 10.9 & 927 & 0.79 & 0.011 \\
\hline SB7 & Sainte Baume & Bedrock & 5.6823 & 43.3189 & 865 & $\begin{array}{c}19.76 \pm \\
0.84 \\
\end{array}$ & 80.83 & 40.2 & $39.4 \pm 4.3$ & 11.6 & 860 & 0.84 & 0.006 \\
\hline GL1 & Grand Luberon & Bedrock & 5.5158 & 43.8192 & 1051 & $8.83 \pm 0.41$ & 25.6 & 39.7 & $85.5 \pm 9.4$ & 9.7 & 1004 & 3.03 & 0.011 \\
\hline GL3 & Grand Luberon & Bedrock & 5.5277 & 43.8196 & 1049 & $6.58 \pm 0.31$ & 22.81 & 40.3 & $116.5 \pm 12.9$ & 9.7 & 1008 & 7.35 & 0.030 \\
\hline GL4 & Grand Luberon & Bedrock & 5.5361 & 43.8182 & 1032 & $\begin{array}{c}12.17 \pm \\
0.48\end{array}$ & 12.06 & 39.6 & $54.6 \pm 5.9$ & 10.3 & 944 & 1.96 & 0.019 \\
\hline LF1 & La Fare & Bedrock & 5.2110 & 43.5625 & 219 & $\begin{array}{c}11.54 \pm \\
0.44 \\
\end{array}$ & 3.78 & 40 & $30.5 \pm 3.3$ & 14.1 & 580 & 2.41 & 0.007 \\
\hline LF2 & La Fare & Bedrock & 5.1963 & 43.5613 & 192 & $8.93 \pm 0.36$ & 6.58 & 40.2 & $41.7 \pm 4.5$ & 14.2 & 562 & 10.53 & 0.009 \\
\hline $\mathrm{CO} 1$ & Costes & Bedrock & 5.2725 & 43.6937 & 477 & $\begin{array}{c}16.49 \pm \\
0.63 \\
\end{array}$ & 3.64 & 40.9 & $23.8 \pm 2.5$ & 12.9 & 709 & 10.22 & 0.063 \\
\hline VE1 & Ventoux & Bedrock & 5.2678 & 44.1743 & 1835 & $\begin{array}{c}21.27 \pm \\
0.76 \\
\end{array}$ & 12.1 & 39.9 & $48.9 \pm 5.2$ & 5.1 & 1484 & 3.44 & 0.064 \\
\hline VE2 & Ventoux & Bedrock & 5.2633 & 44.1740 & 1838 & $\begin{array}{c}33.61 \pm \\
1.16 \\
\end{array}$ & 4.66 & 39.8 & $27 \pm 2.9$ & 5.5 & 1434 & 13.09 & 0.063 \\
\hline VE4 & Ventoux & Bedrock & 5.2749 & 44.1730 & 1851 & $\begin{array}{c}27.27 \pm \\
0.95 \\
\end{array}$ & 7.38 & 39.6 & $35.7 \pm 3.8$ & 5.1 & 1484 & 11.41 & 0.052 \\
\hline VE5 & Ventoux & Bedrock & 5.2604 & 44.1851 & 1440 & $\begin{array}{c}22.60 \pm \\
0.91 \\
\end{array}$ & 16.21 & 38.4 & $35.5 \pm 3.8$ & 7.8 & 1206 & 8.35 & 0.036 \\
\hline LU1 & Lure & Bedrock & 5.7853 & 44.1225 & 1725 & $9.22 \pm 0.46$ & 16.8 & 40.4 & $119.1 \pm 13.3$ & 6.2 & 1377 & 14.77 & 0.025 \\
\hline LU2 & Lure & Bedrock & 5.7887 & 44.1231 & 1751 & $9.79 \pm 0.48$ & 14.14 & 39.4 & $111.1 \pm 12.4$ & 6.2 & 1377 & 12.51 & 0.031 \\
\hline LU3 & Lure & Bedrock & 5.8000 & 44.1232 & 1795 & $8.30 \pm 0.43$ & 20.06 & 40.3 & $141.4 \pm 15.9$ & 5.9 & 1410 & 11.70 & 0.031 \\
\hline SV1 & Sainte Victoire & Bedrock & 5.6182 & 43.5321 & 1012 & $\begin{array}{c}21.78 \pm \\
0.55 \\
\end{array}$ & 13.32 & 39.2 & $26.5 \pm 2.7$ & 11.8 & 822 & 2.74 & 0.004 \\
\hline SV3 & Sainte Victoire & Bedrock & 5.6081 & 43.5310 & 1004 & $\begin{array}{c}24.31 \pm \\
0.65\end{array}$ & 6.76 & 41 & $22.3 \pm 2.3$ & 10.4 & 947 & 2.13 & 0.004 \\
\hline SV4 & Sainte Victoire & Bedrock & 5.6463 & 43.5391 & 1000 & $\begin{array}{c}16.31 \pm \\
0.51 \\
\end{array}$ & 22.45 & 39.8 & $40.3 \pm 4.2$ & 8.3 & 927 & 5.07 & 0.064 \\
\hline
\end{tabular}

Table 1 - Samples for in-situ cosmogenic ${ }^{36} \mathrm{Cl}$ measurement from Provence, SE France, with location information and chemical details of the analysis along with computed denudation rates.

See text for details concerning the estimation of MAP and MAT at the sampling sites. Slopes and 
curvatures have been calculated over circular windows of 21 and 31 meters, respectively, using the IGN RGE $1 \mathrm{~m}$ DEM. 
List of figures

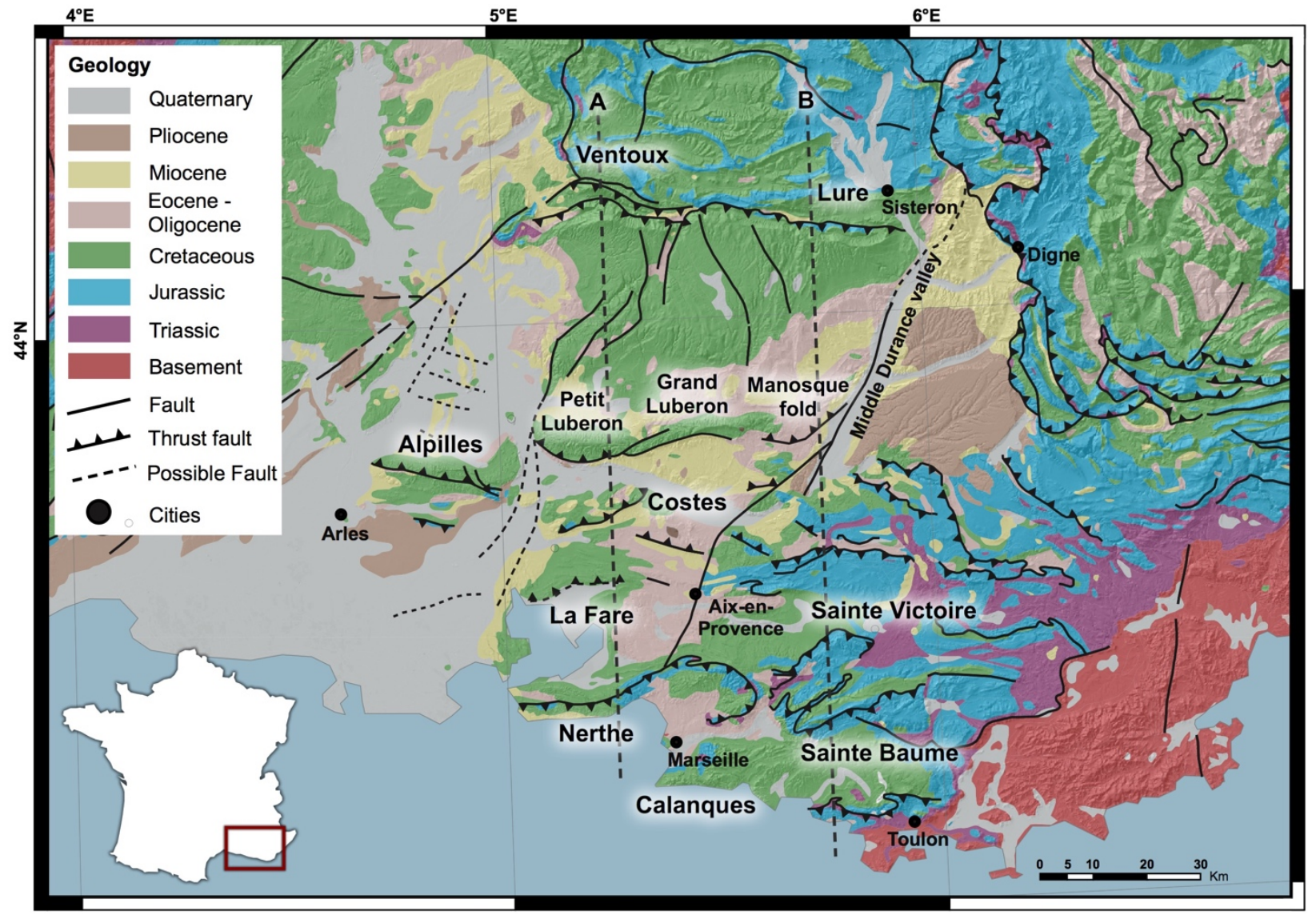

Figure 1 - Geological map of South-Eastern France (modified from Molliex et al., 2011)

showing the principal faults and ranges in Provence. All sampled ranges in this study are indicated. A and B correspond respectively to the western and an eastern topographic profiles discussed below (see figure 7). 

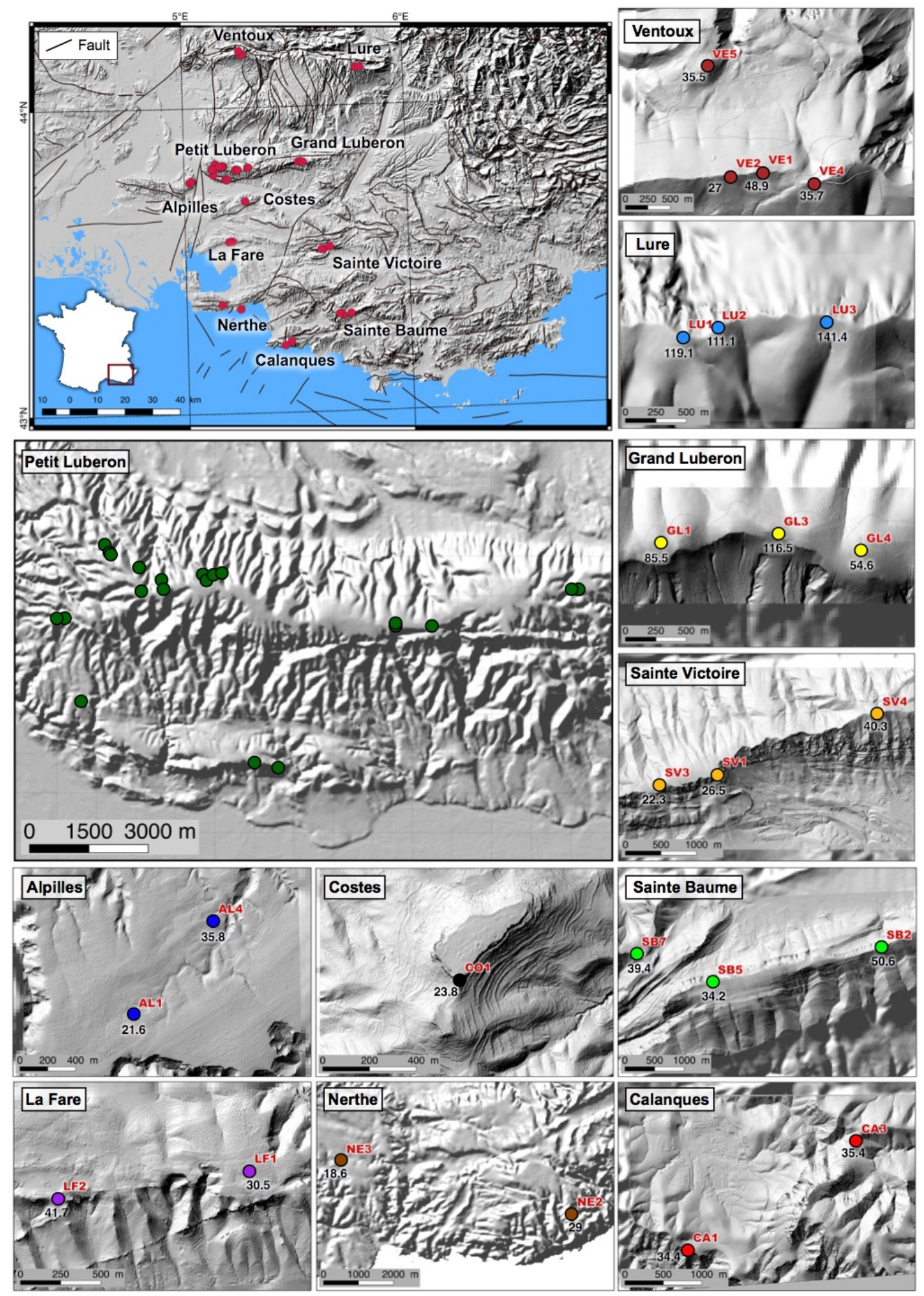

Figure 2 - Upper-left inset: general situation of the sampled sites (red circles) in Western

Provence. The different sampled carbonate ranges are labelled and the main faults indicated in 
black. Other smaller insets: samples distribution for each range. High resolution $(1 \mathrm{~m})$ shaded DEM are used as background and were extracted from the IGN RGE database. The colors of the circles are specific to the sampled mountain range and are used throughout the article. Samples from the Petit Luberon are from Godard et al. (2016) and Thomas et al. (2017). 


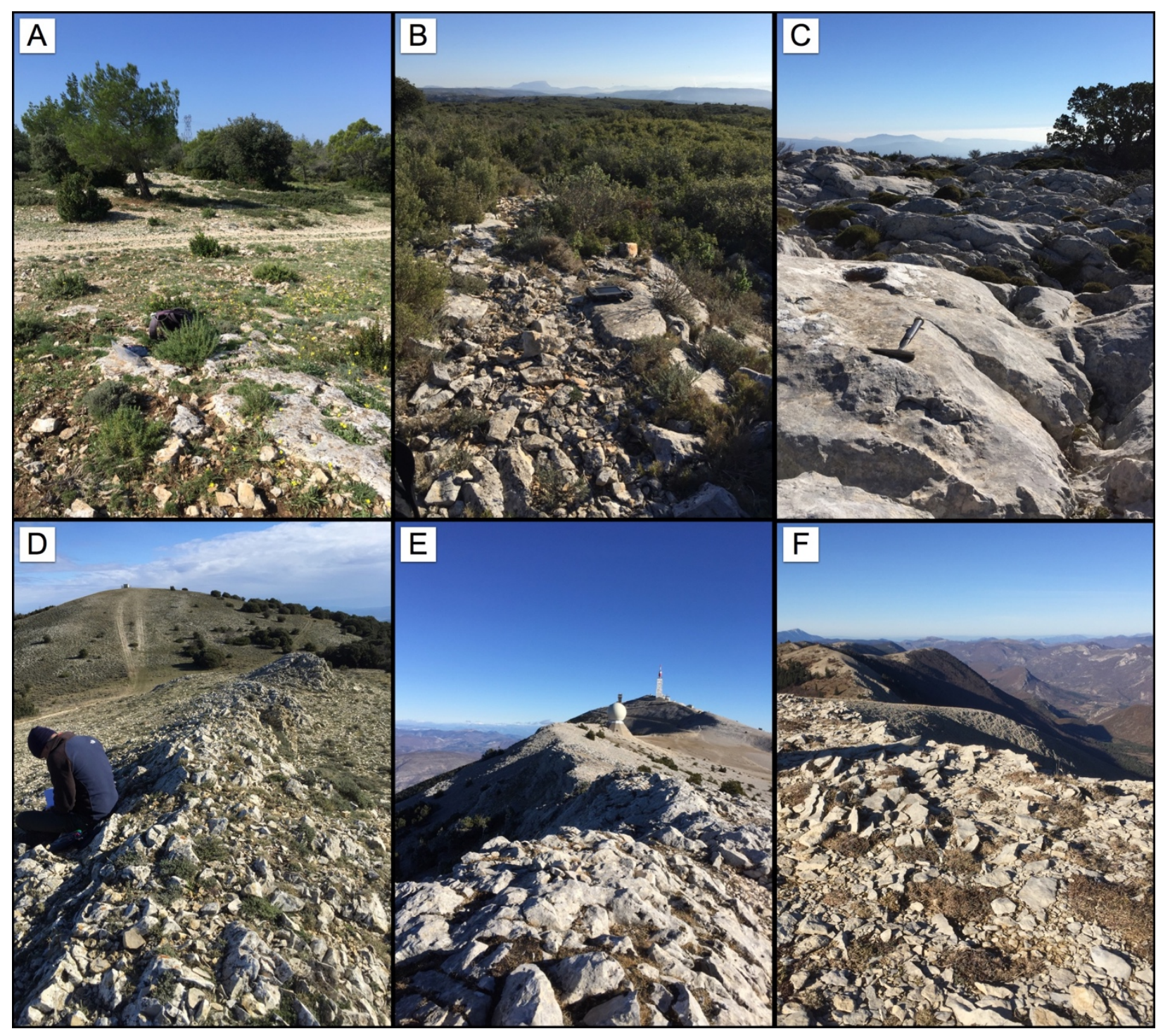

Figure 3 - Field photographs of selected sampling sites. A-B-C: sampling locations on flat plateau surfaces for the Alpilles, La Fare and Sainte Baume mountains respectively. D-E-F: sampling locations on convex crests for the Grand Luberon, Ventoux and Lure mountains respectively. 

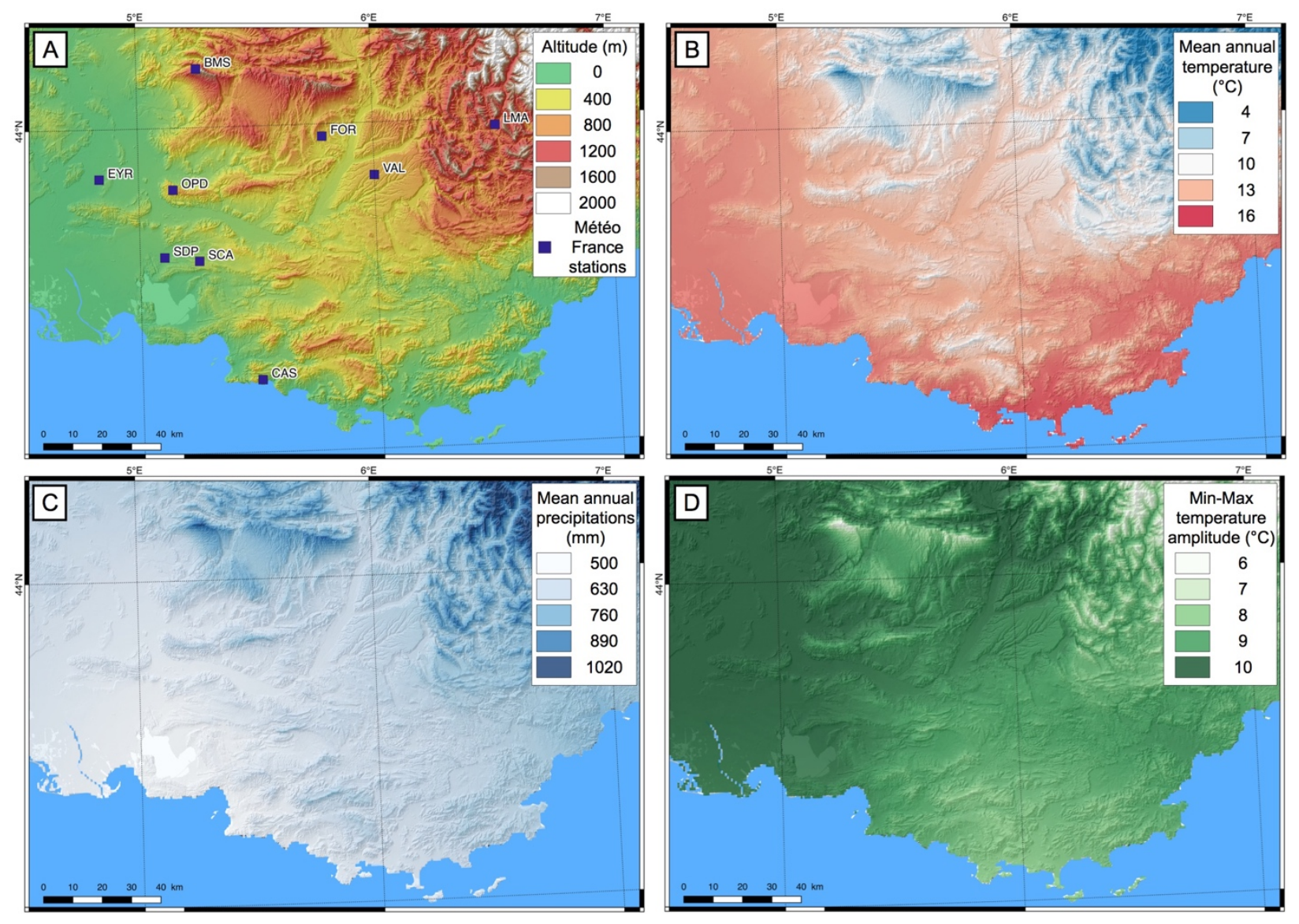

Figure $4-$ A) Topographic map of Provence displaying the location of Météo France weather stations used in this work to calibrate WorldClim gridded (1 km resolution) climatic data (Fick and Hijmans, 2017). B) Mean Annual Temperatures (MAT, in ${ }^{\circ} \mathrm{C}$ ) map of Provence, based on worldclim data. C) Mean Annual Precipitations (MAP, in mm, same source). D) Amplitude between mean annual minimum and mean annual maximum temperature $\left({ }^{\circ} \mathrm{C}\right.$, same source). 

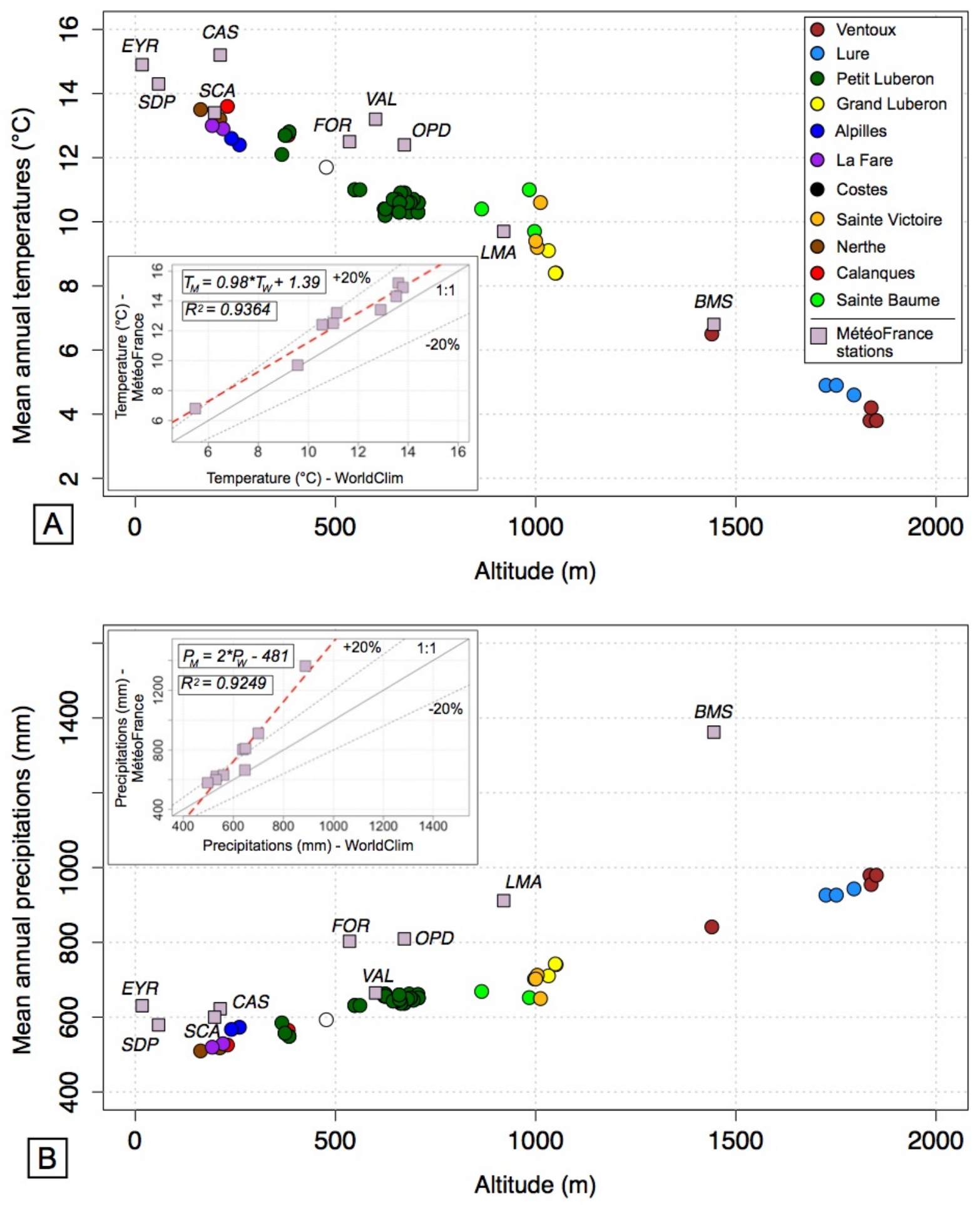

Figure $5-\mathrm{A})$ Mean Annual Temperature (MAT, in ${ }^{\circ} \mathrm{C}$ ) at each sampling site according to WorldClim gridded data and Météo France weather stations (with at least 30 years of available 
annual records), as a function of altitude. B) Mean Annual Precipitations (MAP, in mm) at each sampling site according to WorldClim gridded data and Météo France weather stations, as a function of altitude. The insets are the direct comparisons of the WorldClim and Meteo France data. The red dashed lines are used to compute corrected climatic parameters at the sampling sites. 

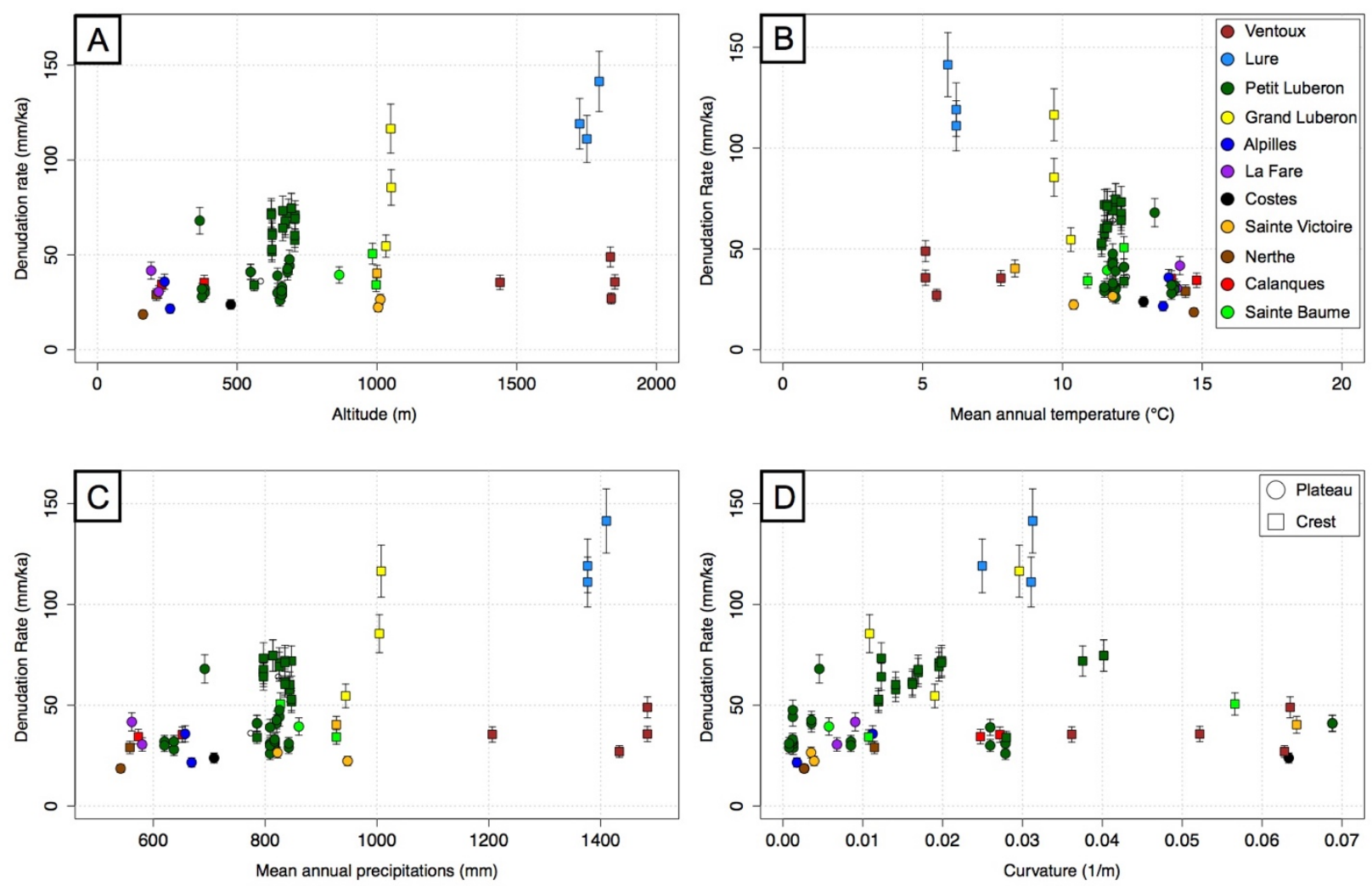

Figure 6 - Denudation rates for bedrock samples compared to various topographic and climatic parameters. Two types of sampling sites are differentiated in the four plots according to the local morphological context at 100 m length scale: plateau surface or crest. A) Denudation rates as a function of sampling site elevation. B) Denudation rates as a function of Mean Annual Temperature $\left({ }^{\circ} \mathrm{C}\right)$ at the sampling location. The temperature values were calculated according to the correction computed from figure 5A. C) Denudation rates as a function of Mean Annual Precipitations $(\mathrm{mm})$ at the sampling location. The precipitation values were calculated according to the correction computed from figure 5B. D) Local curvature calculated over a 30-meter window around each sampling site (Hurst et al., 2012). The 1-meter resolution Digital Elevation Model from IGN RGE was used for the computation. 

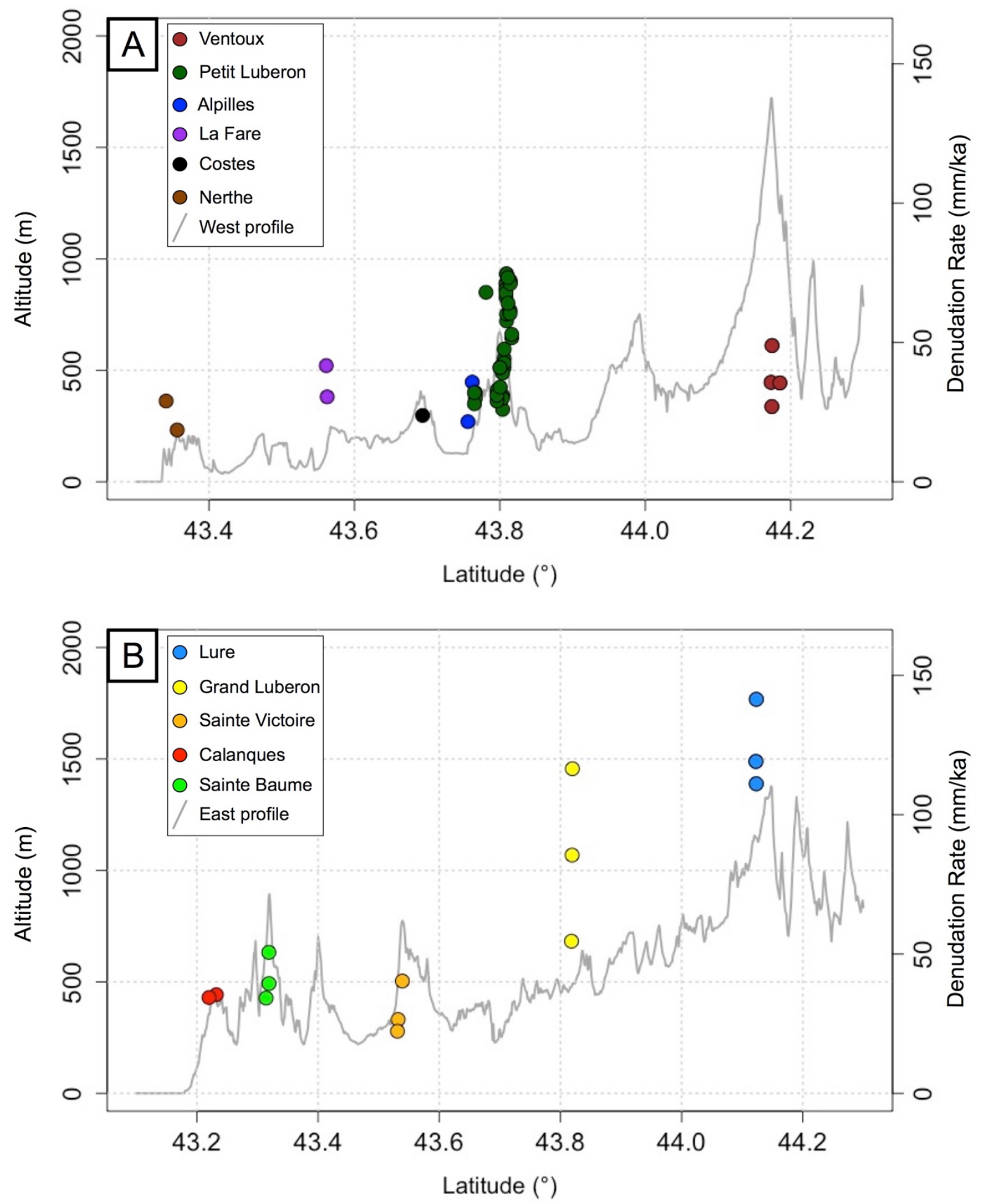

Figure 7 - A) Western topographic profile (see Figure 1 for location) with ${ }^{36} \mathrm{Cl}$ denudation rates. B) Eastern topographic profile (see Figure 1 for location) with ${ }^{36} \mathrm{Cl}$ denudation rates. 

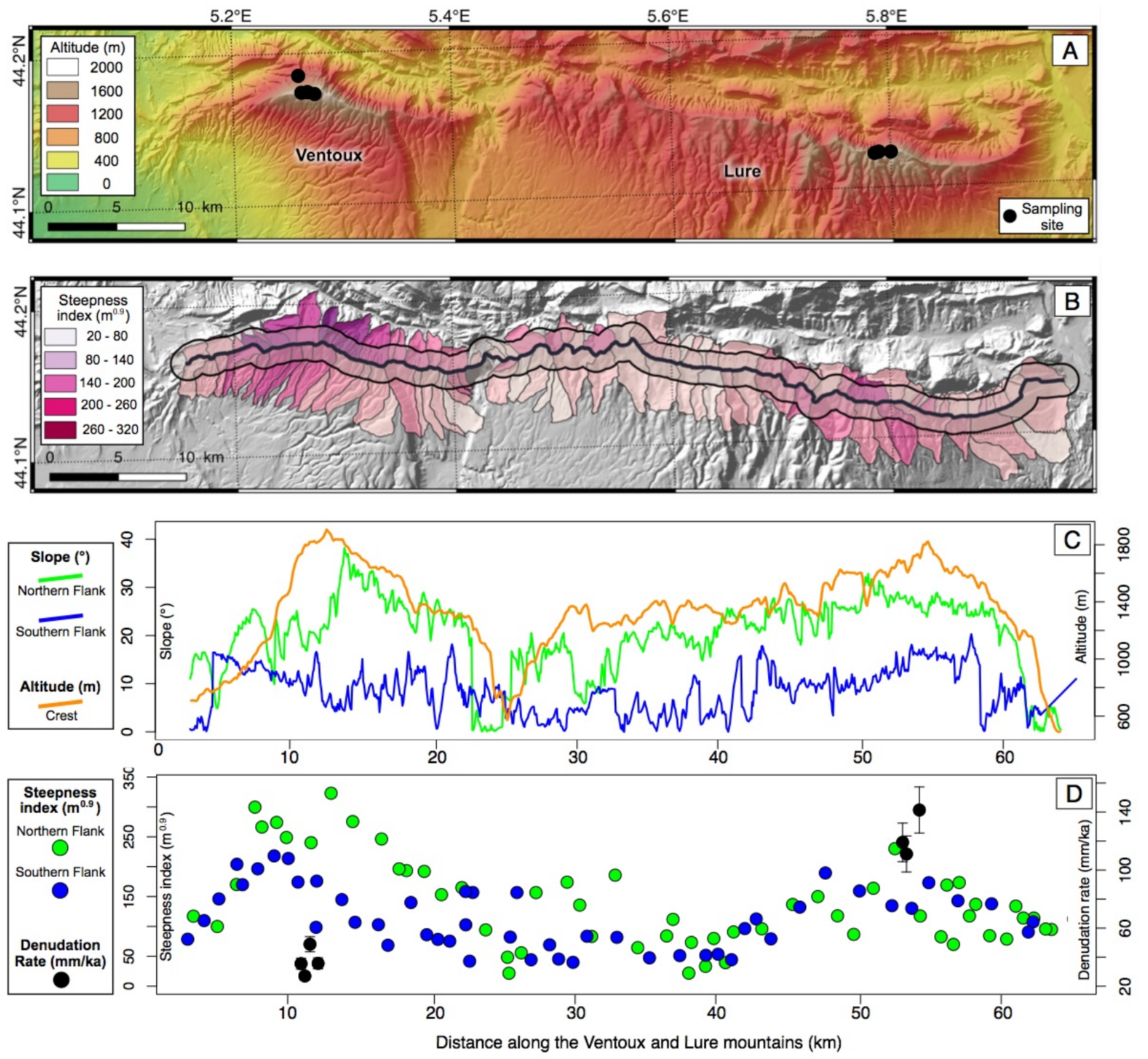

Figure 8 -A) Topographic map of the Ventoux-Lure range displaying the location of samples collected for denudation rates determination (black circles). B) Shaded-relief map showing the Ventoux-Lure crest and a $1.2 \mathrm{~km}$ wide buffer zone for calculation of the average slope of the flanks. Steepness indexes of selected basins (ksn) are also displayed, with on average higher $\mathrm{ks}_{\mathrm{n}}$ on the Ventoux to the West than on the Lure to the East. C) East-West profile along the Ventoux-Lure axis showing the evolution of the crest elevation (orange) and the average slopes of the northern (green) and southern (blue) flanks (see inset B for the extent of the buffer zone 
used for calculation). D) East-West profile along the Ventoux-Lure axis showing the evolution of $\mathrm{ks}_{\mathrm{n}}$ (see inset B for location of the basins) for the northern (green) and southern (blue) flanks. Black circles are ${ }^{36} \mathrm{Cl}$ denudation rates from samples collected in this area. 

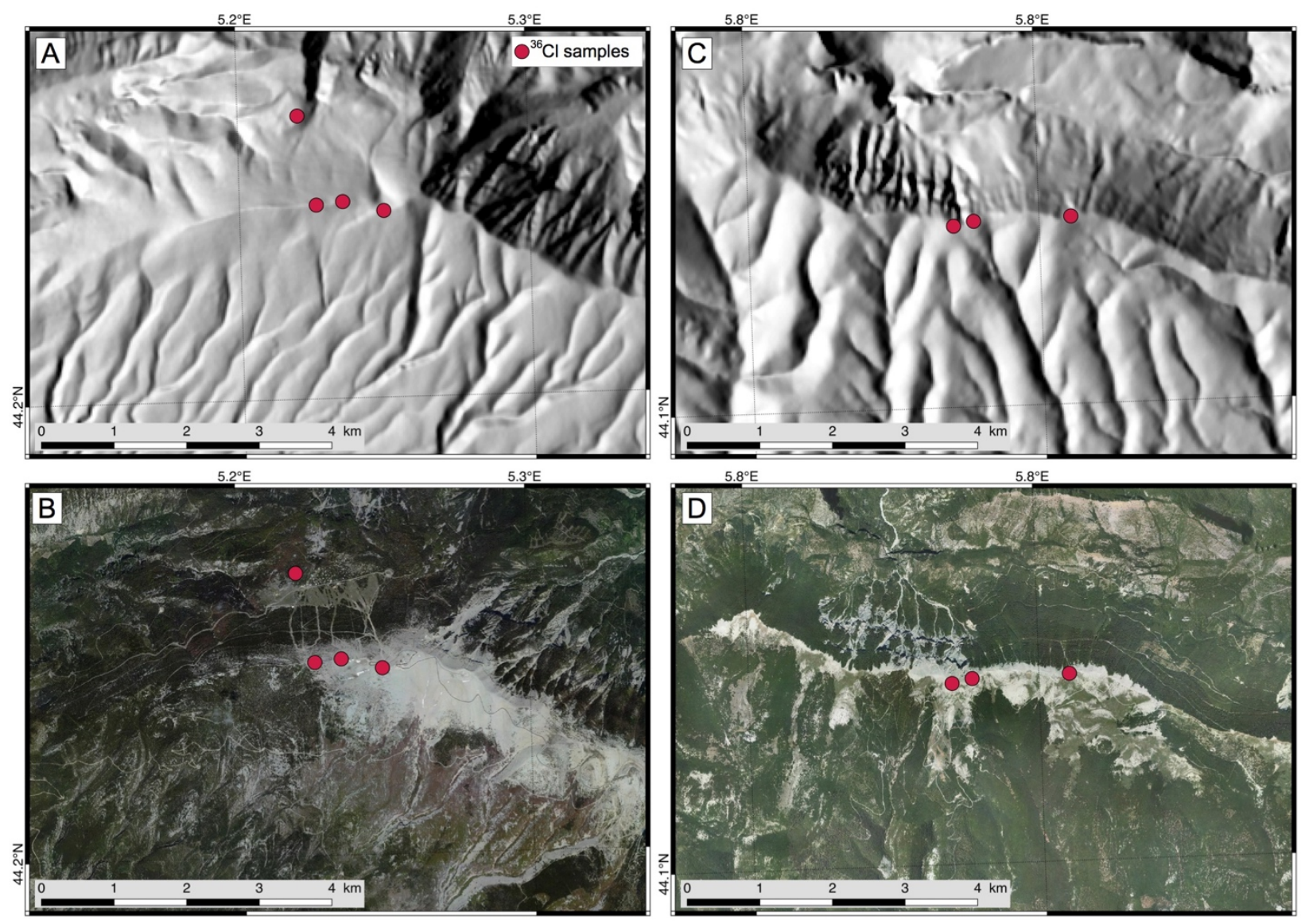

Figure 9 - A) Shaded relief map (25 m IGN DEM) centered on the Ventoux summit area. B) Corresponding orthophotography. C) Shaded relief map (5 m IGN DEM) centered on the Lure mountain summit area showing the greater development of regressive erosion and gullying on the flanks compared to the Ventoux summit. D) Corresponding orthophotography. 


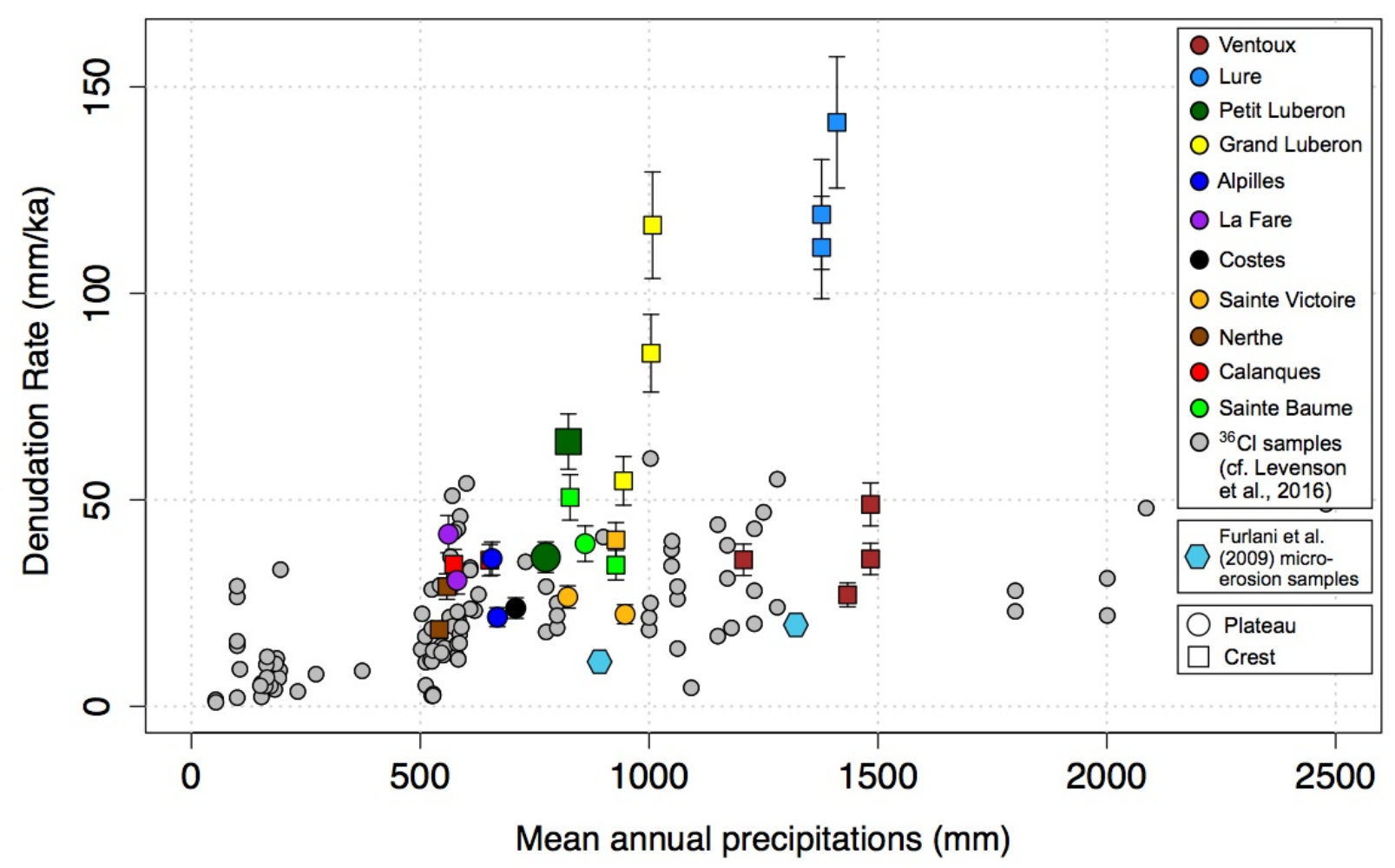

Figure 10 - Denudation rates obtained in Provence (this study, Thomas et al. (2017), Godard et al. (2016)) compared to global carbonate denudation rates determined using in-situ ${ }^{36} \mathrm{Cl}$ (compiled by Levenson et al., 2016). For clarity, denudation rates have been averaged for the Petit Luberon samples depending on their respective location (crest or plateau). Light blue hexagons symbols are results from micro-erosion measurements for Adriatic inland karst samples from Furlani et al. (2009). 


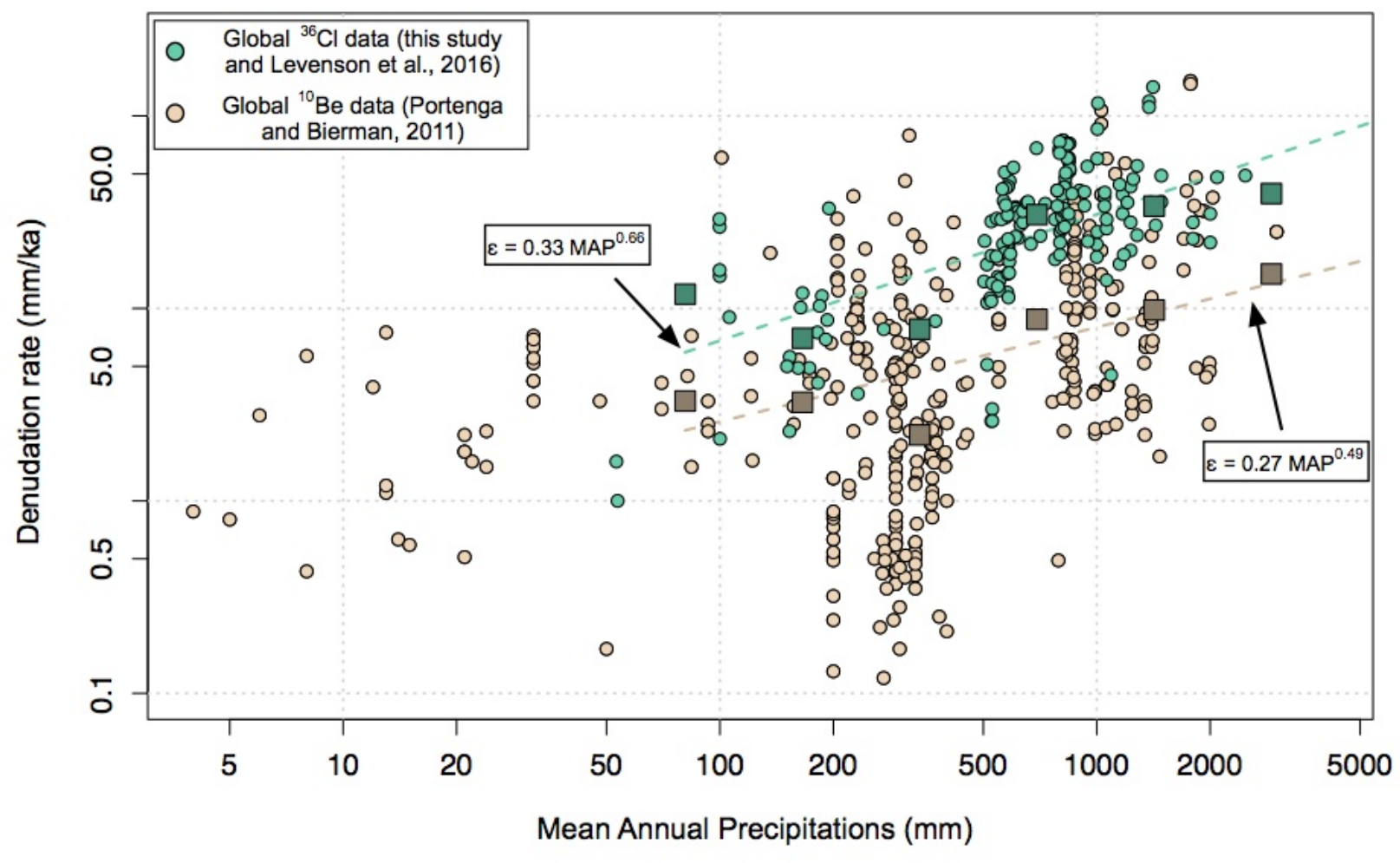

Figure $11-{ }^{36} \mathrm{Cl}$ carbonate denudation rates from this study and Levenson et al. (2016) compilation compared with global bedrock ${ }^{10} \mathrm{Be}$ denudation rates compiled by Portenga et al. (2011). 
References

Arnold, M., Aumaître, G., Bourlès, D. L., Keddadouche, K., Braucher, R., Finkel, R. C., Nottoli, E., Benedetti, L., Merchel, S., 2013. The French accelerator mass spectrometry facility ASTER after 4years: Status and recent developments on ${ }^{36} \mathrm{Cl}$ and ${ }^{129} \mathrm{I}$. Nuclear Instruments and Methods in Physics Research Section B: Beam Interactions with Materials and Atoms, 294, 24-28, doi: 10.1016/j.nimb.2012.01.049

Baroux, E., Béthoux, N., Bellier, O., 2001. Analyses of the stress field in southeastern France from earthquake focal mechanisms. Geophysical Journal International, 145(2), 336-348.

Bestani, L., N. Espurt, J. Lamarche, O. Bellier, F. Hollender, 2016. Reconstruction of the Provence Chain evolution, southeastern France. Tectonics, 35, doi:10.1002/ 2016TC004115.

Bierman, P., Steig, E.J., 1996. Estimating rates of denudation using cosmogenic isotope abundances in sediment, Earth Surface Processes and Landforms, 21, 2, 125-139.

Bookhagen, B., Strecker, M.R., 2012, Spatiotemporal trends in erosion rates across a pronounced rainfall gradient: Examples from the southern Central Andes: Earth and Planetary Science Letters, v. 327-328, p. 97-110, doi: 10.1016/j.eps1.2012.02.005.

Calmels, D., Gaillardet, J., François, L., 2014. Sensitivity of carbonate weathering to soil CO2 production by biological activity along a temperate climate transect, Chemical Geology, 390, 74-86. https://doi.org/10.1016/j.chemgeo.2014.10.010

Champagnac, J.D., Molnar, P., Anderson, R.S., Sue, C., Delacou, B., 2007. Quaternary erosioninduced isostatic rebound in the western Alps. Geology, 35(3), 195-198. http://doi.org/10.1130/G23053A.1

Champion, C., Choukroune, P., Clauzon, G., 2000. La déformation post-Miocène en Provence occidentale. Geodinamica Acta, 13(2), 67-85.

Chardon, C., Bellier, O., 2003. Geological boundary conditions of the 1909 Lambesc (Provence, France) earthquake: Structure and evolution of the Trevaresse ridge anticline, Bull. Soc. Geol. Fr., 174, 497-510. 
Chardon D., Hermitte D., Nguyen F., Bellier O., 2005. First paleoseismological constraints on the strongest earthquake in France (Provence) in the twentieth century, Geology, 33, 11, 901904.

Charreau, J., Blard, P.-H., Puchol, N., Avouac, J.-P., Lallier-Vergès, E., Bourlès, D., Braucher, R., Gallaud, A., Finkel, R., Jolivet, M., Chen, Y., Roy, P., 2011. Paleo-erosion rates in Central Asia since 9Ma: A transient increase at the onset of Quaternary glaciations? Earth and Planetary Science Letters, v. 304, no. 1-2, p. 85-92, doi: 10.1016/j.eps1.2011.01.018.

Clauzon, G., 1982. Le canyon messinien du Rhône : une preuve décisive du "dessicated deepbasin model" (Hsü, Cita et Ryan, 1973). Bull Soc. Geol. France, 24, 597-610.

Cushing, E. M., Bellier, O., Nechtschein, S., Sébrier, M., Lomax, A., Volant, P., Dervin, P., Guignard, P., Bove, L., 2008. A multidisciplinary study of a slow-slipping fault for seismic hazard assessment: the example of the Middle Durance Fault (SE France). Geophysical Journal International, 172(3), 1163-1178.

Dockhorn, B., Neumaier, S., Hartmann, F.J., Petitjean, C., Faestermann, H., Korschinek, G., Morinaga, H., Nolte, E., 1991. Determination of erosion rates with cosmic ray produced $36 \mathrm{Cl}$, Zeitschrift für Physik A Hadrons and Nuclei, 341, 1, 117-11. https://doi.org/10.1007/BF0128128.

DiBiase, R.A., Whipple, K.X., 2011. The influence of erosion thresholds and runoff variability on the relationships among topography, climate, and erosion rate: Journal of Geophysical Research, v. 116, no. F4, p. F04036, doi: 10.1029/2011JF002095.

Dietrich, W.E., Bellugi, D.G., Sklar, L., Stock, J.D., Heimsath, A.M., Roering, J.J., 2003. Geomorphic transport laws for predicting landscape form and dynamics, in Wilcock, P.R. and Iverson, R.M. eds., Prediction in Geomorphology, Geophysical Monograph Series, American Geophysical Union, Washington, D. C., p. 103-132.

Fick, S.E., R.J. Hijmans, 2017. Worldclim 2: New 1-km spatial resolution climate surfaces for global land areas, International Journal of Climatology.

Fifield, L.K., Ophel, T.R., Allan, G.L., Bird, J.R., Davie, R.F., 1990. Accelerator mass spectrometry at the Australian National University's 14UD accelerator: experience and developments, Nuclear Instruments and Methods in Physical Research SectionB, 52, 233. 
Fleurant, C., Tucker, G.E., Viles, H.A., 2008. Modelling cockpit karst landforms: Geological Society, London, Special Publications, 296, 1, 47-62, doi: 10.1144/SP296.4.

Flint, J.J., 1974. Stream gradient as a function of order, magnitude, and discharge, Water Resources Research 10, 969-973.

Furlani, S., Cucchi, F., Forti, F., Rossi, A., 2009. Comparison between coastal and inland Karst limestone lowering rates in the northeastern Adriatic Region (Italy and Croatia). Geomorphology, 104(1), 73-81.

Gabrovšek, F., 2009. On concepts and methods for the estimation of dissolutional denudation rates in karst areas: Geomorphology, 106, 1, 9-14.

Gaillardet, J., Dupré, B., Louvat, P., Allègre, C.J., 1999. Global silicate weathering and CO2 consumption rates deduced from the chemistry of large rivers: Chemical Geology, 159, 1-4, 330, doi: 10.1016/S0009-2541(99)00031-5.

Gasparini, N.M., Whipple, K.X., 2014. Diagnosing climatic and tectonic controls on topography: Eastern flank of the northern Bolivian Andes, Lithosphere, 6, 4, 230-250, doi: 10.1130/L322.1

Gautier, F., Clauzon, G., Suc, J.P., Cravatte, J., Violanti, D., 1994. Age et durée de la crise de salinité messinienne. C. R. Acad. Sci. Paris, Ser. IIa 318, 1103-1109.

George, P., Observations morphologiques autour du mont Ventoux, 1952. Bulletin de 1'Association de géographes français, 29, 226, 89-94.

Godard, V., Bourles, D.L., Spinabella, F., Burbank, D.W., Bookhagen, B., Fisher, G.B., Moulin, A., Leanni, L., 2014. Dominance of tectonics over climate in Himalayan denudation: Geology, v. 42, no. 3, p. 243-246, doi: 10.1130/G35342.1.

Godard, V., Ollivier, V., Bellier, O., Miramont, C., Shabanian, E., Fleury, J., Benedetti, L., Guillou, V., ASTER Team, 2016. Weather-limited hillslope evolution in carbonate landscapes, Earth Planet. Sci. Lett., 446, 10-20.

Gosse, J.C., Phillips, F.M., 2001. Terrestrial in situ cosmogenic nuclides: theory and application: Quaternary Science Reviews, 20, 14, 1475-1560, doi: 10.1016/S0277-3791(00)00171-2. 
Granger, D. E., Kirchner, J. W., Finkel, R., 1996. Spatially averaged long-term erosion rates measured from in situ-produced cosmogenic nuclides in alluvial sediment, J. Geol., 104(3), 249257.

Granger, D.E., Riebe, C.S., 2013, Cosmogenic Nuclides in Weathering and Erosion: Treatise on Geochemistry: Second Edition, v. 7, p. 401-436, doi: 10.1016/B978-0-08-095975-7.00514-3.

Gran Mitchell, S., Matmon, A., Bierman, P.R., Enzel, Y., Caffee, M., Rizzo, D., 2001. Displacement history of a limestone normal fault scarp, northern Israel, from cosmogenic 36Cl. J. Geophys. Res. 106, 4247-4264.

Hack, J.T., 1957. Studies of Longitudinal Stream Profiles in Virginia and Maryland, U.S. Geological Survey Professional Paper 294-B, 97.

Harel, M., Mudd, S.M., Attal, M., 2016. Global analysis of the stream power law parameters based on worldwide 10Be denudation rates: Geomorphology, v. 268, p. 184-196, doi: 10.1016/j.geomorph.2016.05.035.

Hartmann, J., Moosdorf, N., 2012. The new global lithological map database GLiM: A representation of rock properties at the Earth surface: Geochemistry, Geophysics, Geosystems, v. 13, no. 12, p. 1-37, doi: 10.1029/2012GC004370.

Hilley, G.E., Chamberlain, C.P., Moon, S., Porder, S., Willett, S.D., 2010. Competition between erosion and reaction kinetics in controlling silicate-weathering rates: Earth and Planetary Science Letters, 293, 1-2, 191-199, doi: 10.1016/j.eps1.2010.01.008.

Howard, A.D., Kerby, G., 1983. Channel changes in badlands. Geological Society of America Bulletin 94, 739-752.

Hurst, M.D., Mudd, S.M., Walcott, R., Attal, M., Yoo, K., 2012. Using hilltop curvature to derive the spatial distribution of erosion rates: Journal of Geophysical Research, v. 117, no. F2, p. F02017, doi: 10.1029/2011JF002057.

Kaufmann, G., Braun, J., 2002. Modelling karst denudation on a synthetic landscape: Terra Nova, 13, 5, 313-320, doi: 10.1046/j.1365-3121.2001.00345.x. 
Kirby, E., Whipple, K. X., Tang, W., Chen, Z., 2003. Distribution of active rock uplift along the eastern margin of the Tibetan Plateau: Inferences from bedrock channel longitudinal profiles, J. Geophys. Res., 108(B4), 2217, doi:10.1029/2001JB000861.

Kirby, E., Whipple, K., 2012. Expression of active tectonics in erosional landscapes. Journal of Structural Geology, 44, 54-75.

Kirchner, J.W., Finkel, R.C., Riebe, C.S., Granger, D.E., Clayton, J.L., King, J.G., Megahan, W.F., 2001. Mountain erosion over 10 yr, 10 k.y., and 10 m.y. time scales: Geology, 29, 7, 591594, doi: 10.1130/0091-7613

Kirstein, J., Hellevang, H., Haile, B.G., Gleixner, G., Gaupp, R., 2016. Experimental determination of natural carbonate rock dissolution rates with a focus on temperature dependency: Geomorphology, 261, 30-40, doi: 10.1016/j.geomorph.2016.02.019.

Krijgsman, W., Hilgen, F. J., Raf, I., Sierro, F. J., Wilson, D.S., 1999. Chronology, causes and progression of the Messinian salinity crisis. Letters to Nature, 400, 652-655.

Lal, D., 1991. Cosmic ray labeling of erosion surfaces: in situ nuclide production rates and erosion models. Earth Planet. Sci. Lett. 104, 424-439.

Levenson, Y., Ryb, U., Emmanuel, S., 2017. Comparison of field and laboratory weathering rates in carbonate rocks from an Eastern Mediterranean drainage basin. Earth and Planetary Science Letters, 465, 176-183. http://doi.org/10.1016/j.epsl.2017.02.031

Liu, Z., Yuan, D., and Dreybrodt, W., 2005. Comparative study of dissolution rate-determining mechanisms of limestone and dolomite: Environmental Geology, 49, 2, 274-279, doi: 10.1007/s00254-005-0086-z.

Marrero, S.M., Phillips, F.M., Borchers, B., Lifton, N., Aumer, R., Balco, G., 2016. Quaternary Geochronology Cosmogenic nuclide systematics and the CRONUScalc program, Quaternary Geochronology, 31, 160-187. http://doi.org/10.1016/j.quageo.2015.09.005

Marshall, J.A., Roering, J.J., Bartlein, P.J., Gavin, D.G., Granger, D.E., Rempel, A.W., Praskievicz, S.J., Hales, T.C., 2015. Frost for the trees : Did climate increase erosion in unglaciated landscapes during the late Pleistocene ?, Science Advances, , no. November, doi: 10.1126/sciadv.1500715. 
Matsushi, Y., Sasa, K., Takahashi, T., Sueki, K., Nagashima, Y., Matsukura, Y., 2010. Denudation rates of carbonate pinnacles in Japanese karst areas: estimates from cosmogenic $36 \mathrm{Cl}$ in calcite. Nuclear Instruments and Methods in Physics Research, 268, 1205-1208.

Miramont, C., Rosique, T., Sivan, O., Edouard, J-L., Magnin, F., Talon, B., 2004. The "main postglacial" sedimentation cycle of marly subalpine basins : an inventory. Méditerranée, 102, 7184, doi : 10.3406/medit.2004.3342.

Mocochain, L., Audra, P., Clauzon, G., Bellier, O., Bigot, J. Y., Parize, O., Monteil, P., 2009. The effect of river dynamics induced by the Messinian Salinity Crisis on karst landscape and caves: Example of the Lower Ardèche river (mid Rhône valley), Geomorphology, 106(1-2), 4661.

Molliex S., Bellier, O., Terrier, M., Lamarche, J., Martelet, G., Espurt, N., 2011. Tectonic and sedimentary inheritance on the structural framework of Provence (SE France): Importance of the Salon-Cavaillon fault, Tectonophysics, 501, 1-16.

Mudd, S.M., Yoo, K., Gabet, E.J., 2013. Influence of Chemical Weathering on Hillslope Forms, in Treatise on Geomorphology, Elsevier, p. 56-65.

Nocquet, J.M., 2012. Present-day kinematics of the Mediterranean: A comprehensive overview of GPS results, Tectonophysics, 579, 220-242.

Olen, S.M., Bookhagen, B., Strecker, M.R., 2016. Role of climate and vegetation density in modulating denudation rates in the Himalaya. Earth and Planetary Science Letters, 445, 57-67, doi: 10.1016/j.eps1.2016.03.047

Ouimet, W.B., Whipple, K.X., and Granger, D.E., 2009, Beyond threshold hillslopes: Channel adjustment to base-level fall in tectonically active mountain ranges: Geology, v. 37, no. 7, p. 579-582, doi: 10.1130/G30013A.1.

Perron, J.T., Kirchner, J.W., Dietrich, W.E., 2009. Formation of evenly spaced ridges and valleys: Nature, 460, 7254, 502-505, doi: 10.1038/nature08174.

Plan, L., 2005. Factors controlling carbonate dissolution rates quantified in a field test in the Austrian alps: Geomorphology, 68, 3-4, 201-212, doi: 10.1016/j.geomorph.2004.11.014. 
Portenga, E. W., Bierman, P. R., 2011. Understanding earth's eroding surface with ${ }^{10}$ Be. GSA Today, 21(8), 4-10. http://doi.org/10.1130/G111A.1

Riebe, C.S., Kirchner, J.W., Granger, D.E., Finkel, R.C., 2001. Strong tectonic and weak climatic control of long-term chemical weathering rates: Geology, 29, 6, 511-514, doi: 10.1130/0091-7613(2001)029

Roe, G.H., Montgomery, D.R., Hallet, B., 2003. Orographic precipitation and the relief of mountain ranges. Journal of Geophysical Research, 108(B6), 2315, doi: 10.1029/2001JB001521

Roering, J.J., Kirchner, J.W., and Dietrich, W.E., 2001. Hillslope evolution by nonlinear, slopedependent transport: Steady state morphology and equilibrium adjustment timescales: Journal of Geophysical Research, v. 106, no. B8, p. 16499-16513, doi: 10.1029/2001JB9000323.

Roure, F., Brun, J.-P., Colletta, B., Van Den Driessche, J., 1992. Geometry and kinematics of extensional structures in the alpine foreland basin of southeastern France. Journal of Structural Geology, 14(5), 503-519.

Rosique, T., 2004. The last glacial phase in the middle Durance (region from Gap to Sisteron): research appraisal, latest chronological conclusions. Méditerranée, 102, 25-36. doi : 10.3406/medit.2004.3336

Ryb, U., Matmon, A., Erel, Y., Haviv, I., Benedetti, L., and Hidy, A.J., 2014a. Styles and rate of long-term denudation in carbonate terrains under a Mediterranean to hyper-arid climatic gradient, Earth and Planetary Science Letters, 406, 142-152. Ryb, U., Matmon, A., Erel, Y., Haviv, I., Katz, A., Starinsky, A., Angert, A., and Team, A., 2014b. Controls on denudation rates in tectonically stable Mediterranean carbonate terrain, Geological Society of America Bulletin, 126, 3-4, 553-568. Ryb, U., Matmon, A., Haviv, I., and Benedetti, L., 2015. Exhumation and uplift coupled with precipitation along the western Dead Sea Rift margin, Geology, 43, 6, 483-486.

Sadier, B., Delannoy, J-J., Benedetti, L., Bourlès, D., Jaillet, S., Geneste, J-M., Lebatard, A-E., Arnold, M., 2012. Further constraints on the Chauvet cave artwork elaboration, Proceeding of the national academy of sciences, $109,21,8002-8006$.

Schaller, M., von Blanckenburg, F., Veldkamp, A., Tebbens, L.A., Hovius, N., Kubik, P.W., 2002. A $30000 \mathrm{yr}$ record of erosion rates from cosmogenic ${ }^{10} \mathrm{Be}$ in Middle European river 
terraces. Earth and Planetary Science Letters, 204(1-2), 307-320, doi: 10.1016/S0012$821 \mathrm{X}(02) 00951-2$

Schaller, M., Ehlers, T.A., Lang, K.A. H., Schmid, M., Fuentes-Espoz, J.P., 2018. Addressing the contribution of climate and vegetation cover on hillslope denudation, Chilean Coastal Cordillera (26-38S), Earth and Planetary Science Letters, 489, 111-122. https://doi.org/10.1016/j.epsl.2018.02.026

Scherler, D., DiBiase, R.A., Fisher, G.B., Avouac, J.P., 2017. Testing monsoonal controls on bedrock river incision in the Himalaya and Eastern Tibet with a stochastic-threshold stream power model: Journal of Geophysical Research: Earth Surface, 122, 7, 1389-1429, doi: 10.1002/2016JF004011.

Schimmelpfennig, I., Benedetti, L., Finkel, R., Pik, R., Blard, P. H., Bourlès, D., Burnard, P., Williams, A., 2009. Sources of in-situ ${ }^{36} \mathrm{Cl}$ in basaltic rocks. Implications for calibration of production rates. Quaternary Geochronology, 4(6), 441-461. http://doi.org/10.1016/j.quageo.2009.06.003

Schimmelpfennig, I., Benedetti, L., Garreta, V., Pik, R., Blard, P.-H., Burnard, P., Bourlès, D., Finkel, R., Ammon, K., Dunai, T., 2011. Calibration of cosmogenic ${ }^{36} \mathrm{Cl}$ production rates from $\mathrm{Ca}$ and $\mathrm{K}$ spallation in lava flows from Mt. Etna $\left(38^{\circ} \mathrm{N}\right.$, Italy) and Payun Matru $\left(36^{\circ} \mathrm{S}\right.$, Argentina). Geochimica et Cosmochimica Acta, 75(10), 2611-2632.

Schlagenhauf, A., Gaudemer, Y., Benedetti, L., Manighetti, I., Palumbo, L., Schimmelpfennig, I., Finkel, R., Pou, K., 2010. Using in situ Chlorine-36 cosmonuclide to recover past earthquake histories on limestone normal fault scarps: A reappraisal of methodology and interpretations: Geophysical Journal International, 182, 36-72, doi: 10.1111/j.1365-246X.2010.04622.x.

Sharma, P., Kubik, P.W., Fehn, U., Gove, H.E., Nishiizumi, K., Elmore, D., 1990. Development of ${ }^{36} \mathrm{Cl}$ standards for AMS, Nuclear Instruments and Methods in Physics Research Section B: Beam Interactions with Materials and Atoms, B52, 410.

Siame, L., Bellier O., Braucher R., Sébrier M., Cushing M., Bourlès D., Hamelin B., Baroux E., De Voogde B., Raisbeck G., Yiou F., 2004. Local erosion rates versus active tectonics: cosmic ray exposure modelling in Provence (south-east France), Earth Planet. Sci. Lett., 220(3-4), 345364. 
Stone, J., Allan, G. L., Fifield, L. K., Evans, J. M., Chivas, A. R., 1994. Limestone erosion measurements with cosmogenic chlorine-36 in calcite - preliminary results from Australia. Nuclear Instruments and Methods in Physics Research, B92, 311-316.

Stone, J. O., 2000. Air pressure and cosmogenic isotope production. Journal of Geophysical Research, 105(B10), 23753-23759. http://doi.org/10.1029/2000JB900181

Thinon, M., 2007. La végétation du mont Ventoux au cours des derniers millénaires, Forêt Méditerranéenne, t. XXVIII, 4.

Thomas, F., Godard, V., Bellier, O., Shabanian, E., Ollivier, V., Benedetti, L., Rizza, M., Espurt, N., Guillou, V., Hollender, F., Molliex, S., ASTER Team, 2017. Morphological controls on the dynamics of carbonate landscapes under a mediterranean climate, Terra Nova, 29, 3, 173-182. http://doi.org/10.1111/ter.12260

Thorn, C.E., Darmody, R.G., Dixon, J.C., Schlyter, P., 2002. Weathering rates of buried machine-polished rock disks, Kärkevagge, Swedish Lapland: Earth Surface Processes and Landforms, 27, 8, 831-845, doi: 10.1002/esp.355.

Tofelde, S., Schildgen, T.F., Savi, S., Pingel, H., Wickert, A. D., Bookhagen, B., Wittman, H., Alonso, R.N., Cottle, J., Strecker, M.R., 2017. 100 kyr fluvial cut-and-fill terrace cycles since the Middle Pleistocene in the southern Central Andes, NW Argentina. Earth and Planetary Science Letters, 473, 141-153, doi: 10.1016/j.eps1.2017.06.001

Torres Acosta, V., Schildgen, T.F., Clarke, B.A., Scherler, D., Bookhagen, B., Wittmann, H., Von Blackenburg, F., Strecker, M.R., 2015. Effect of vegetation cover on millennial-scale landscape denudation rates in East Africa, Lithosphere, 7(4), 408-420. https://doi.org/10.1130/L402.1

Trudgill, S.T., Ferguson, R.I., Ball, J., Crabtree, R.W., Gent, R., 1994. Ten year remeasurement of chemical denudation on a magnesian limestone hillslope: Earth Surface Processes and Landforms, v. 19, no. 2, p. 109-114, doi: 10.1002/esp.3290190203.

Tucker, G.E., Slingerland, R., 1997. Drainage basin responses to climate change: Water Resources Research, v. 33, no. 8, p. 2031-2047, doi: 10.1029/97WR00409. 
Von Blanckenburg, F., 2005. The control mechanisms of erosion and weathering at basin scale from cosmogenic nuclides in river sediment: Earth and Planetary Science Letters, 237, 3-4, 462479.

Whipple, K.X., Tucker, G.E., 2002. Implications of sediment-flux-dependent river incision models for landscape evolution: Journal of Geophysical Research, 107, B2, 2039, doi: 10.1029/2000JB000044.

Williams, P.W., Ford, D.C., 2006. Global distribution of carbonate rocks, Zeitschrift für Geomorphologie N.F., Suppl.-Vol. 147, p. 1-2.

Wobus, C., Whipple, K.X., Kirby, E., Snyder, N., Johnson, J., Spyropolou, K., Crosby, B., Sheehan, D., 2006. Tectonics from topography: procedures, promise, and pitfalls, Geological Society of America Special Paper, 398, 55-74, doi: 10.1130/0-8137-2398-1

Xu, S., Liu, C., Freeman, S., Lang, Y., Schnabel, C., Tu, C., Wilcken, K., Zhao, Z., 2013. In-situ cosmogenic $36 \mathrm{Cl}$ denudation rates of carbonates in Guizhou karst area. Chinese Science Bulletin, 58, 2473-2479.

Zerathe, S., Braucher, R., Lebourg, T., Bourlès, D., Manetti, M., Léanni, L., 2013. Dating chert (diagenetic silica) using in-situ produced ${ }^{10} \mathrm{Be}$ : Possible complications revealed through a comparison with ${ }^{36} \mathrm{Cl}$ applied to coexisting limestone, Quaternary Geochronology, 17, 81-93. 